\title{
Physical and mechanical cues affecting biomaterial-mediated plasmid DNA delivery: insights into non-viral delivery systems
}

Valeria Graceffa ${ }^{1,2}$ (D)

\begin{abstract}
Background: Whilst traditional strategies to increase transfection efficiency of non-viral systems aimed at modifying the vector or the polyplexes/lipoplexes, biomaterial-mediated gene delivery has recently sparked increased interest. This review aims at discussing biomaterial properties and unravelling underlying mechanisms of action, for biomaterial-mediated gene delivery. DNA internalisation and cytoplasmic transport are initially discussed. DNA immobilisation, encapsulation and surface-mediated gene delivery (SMD), the role of extracellular matrix (ECM) and topographical cues, biomaterial stiffness and mechanical stimulation are finally outlined.

Main text: Endocytic pathways and mechanisms to escape the lysosomal network are highly variable. They depend on cell and DNA complex types but can be diverted using appropriate biomaterials. 3D scaffolds are generally fabricated via DNA immobilisation or encapsulation. Degradation rate and interaction with the vector affect temporal patterns of DNA release and transgene expression. In SMD, DNA is instead coated on 2D surfaces. SMD allows the incorporation of topographical cues, which, by inducing cytoskeletal re-arrangements, modulate DNA endocytosis. Incorporation of ECM mimetics allows cell type-specific transfection, whereas in spite of discordances in terms of optimal loading regimens, it is recognised that mechanical loading facilitates gene transfection. Finally, stiffer 2D substrates enhance DNA internalisation, whereas in 3D scaffolds, the role of stiffness is still dubious.

Conclusion: Although it is recognised that biomaterials allow the creation of tailored non-viral gene delivery systems, there still are many outstanding questions. A better characterisation of endocytic pathways would allow the diversion of cell adhesion processes and cytoskeletal dynamics, in order to increase cellular transfection. Further research on optimal biomaterial mechanical properties, cell ligand density and loading regimens is limited by the fact that such parameters influence a plethora of other different processes (e.g. cellular adhesion, spreading, migration, infiltration, and proliferation, DNA diffusion and release) which may in turn modulate gene delivery. Only a better understanding of these processes may allow the creation of novel robust engineered systems, potentially opening up a whole new area of biomaterial-guided gene delivery for non-viral systems.
\end{abstract}

Keywords: Biomaterial-mediated gene delivery, Surface-mediated gene delivery, Non-viral gene delivery systems, Mechanical cues, Extracellular matrix cues, Topographic cues

Correspondence: graceffa.valeria@itsligo.ie

${ }^{1}$ Cellular Health and Toxicology Research Group (CHAT), Institute of Technology Sligo, Ash Ln, Bellanode, Sligo, Ireland

${ }^{2}$ Department of Life Sciences, Institute of Technology Sligo, Ash Ln, Bellanode, Sligo, Ireland

(c) The Author(s). 2021 Open Access This article is licensed under a Creative Commons Attribution 4.0 International License, which permits use, sharing, adaptation, distribution and reproduction in any medium or format, as long as you give appropriate credit to the original author(s) and the source, provide a link to the Creative Commons licence, and indicate if changes were made. The images or other third party material in this article are included in the article's Creative Commons licence, unless indicated otherwise in a credit line to the material. If material is not included in the article's Creative Commons licence and your intended use is not permitted by statutory regulation or exceeds the permitted use, you will need to obtain permission directly from the copyright holder. To view a copy of this licence, visit http://creativecommons.org/licenses/by/4.0/. 


\section{Background}

Numerous are the applications of gene therapy and span from the treatment of genetic diseases to the reduction of inflammatory processes [1], tissue engineering [2] and stem cell differentiation [3]. Concomitantly, several challenges and setbacks are still limiting their clinical implementation. In spite of high transfection efficiency, viral transfection systems arise safety concerns, with few deaths being reported during viral-based gene therapy trials [4-6]. On the other hand, non-viral systems cross the plasma membrane barrier, escape lysosomal degradation and are delivered to the nucleus, less efficiently than viral ones [7].

Whilst traditional strategies to increase efficiency of non-viral systems aimed at modifying the vector or optimising the design of polyplexes/lipoplexes, biomaterialmediated gene delivery has recently sparked increased interest within the scientific community. DNA polyplexes or lipoplexes can be embedded, immobilised or coated on biomaterials. Not only do the biomaterials increase localisation at the desired site, offer a support for cells to grow and a mechanical support $[2,8]$, but they also directly modulate transfection efficiency. As a matter of fact, cell embedding [9], cell adhesion $[10,11]$ and migration [12, 13] influence cytoskeletal arrangement and focal adhesions, ultimately affecting DNA internalisation and nuclear transport. Biomaterial-mediated gene delivery systems generally result in a higher transfection [14-16] and even reduced cytotoxicity [15], than traditional ones. For instance, 3D culture systems containing mineral-coated microparticles releasing DNA polyplexes resulted in a higher transfection rate of human mesenchymal stem cells (MSCs), compared to bolus delivery. This was attributed to an increase in macropinocytosismediated DNA uptake [17]. Different cell seeding strategies may further modulate transfection efficacy and temporal pattern of transgene expression. For instance, NIH3T3 murine fibroblasts, if embedded into fibrin hydrogels containing Lipofectamine ${ }^{\mathrm{Tm}}$ (Invitrogen) complexes, were more efficiently transfected, than when seeded on top of the gels. The former approach was also less reliant on biomaterial degradation [15]. Similarly, another study found an initial lower transfection rate, but a prolonged transgene expression, for cells seeded on top of hydrogels, compared to cells encapsulated within the gels [18].

A drawback of many non-viral systems is their inability to integrate plasmid DNA. However, especially in the case of non-cycling cells, which show a reduced tendency to lose episomal DNA [19], episomal maintenance of vectors would be in fact desirable over random integration for toxicity, safety-related concerns and technical complexity [20]. By combining optimal biomaterials with non-viral systems, a sufficient prolonged transgene expression can be achieved. For instance, in immunocompetent murine models [20-24], sustained transgene expression in vivo in the retina was demonstrated for even 6 months [20] and 2 years [25], in the skeletal muscle for at least two [21] and 19 months [24], whereas subcutaneously implanted poly(lactic-co-glycolic acid) (PLGA) scaffolds allowed expression of the transgene for at least 28 weeks [23] and 126 days [22].

However, parameters determining temporal pattern of gene expression and efficacy of transfection are not only limited to the dimensionality and to the cell seeding approach. Interaction between cells, biomaterial and DNA is in fact extremely complex and mechanisms involved are still not fully understood. This review proposes to critically discuss biomaterial properties and to unravel underlying mechanisms of action that need to be considered when designing a biomaterial-mediated gene delivery system. Mechanisms of lipoplex/polyplex internalisation and nuclear delivery are initially discussed, as their understanding allows development of targeted approaches. Differences between DNA immobilisation, encapsulation and surface-mediated delivery (SMD) are then highlighted. The effect of extracellular matrix (ECM) mimetics, biomaterial stiffness and mechanical stimulation is finally outlined.

\section{Main text}

\section{DNA delivery and trafficking within the cells}

Common DNA delivery systems are polyplexes, lipoplexes and nioplexes. The former are composed of polymers, whose positive charge enables binding to DNA molecules and facilitates interaction with cell membrane [26]. Lipoplexes are instead complexes of DNA, cationic and neutral lipids [27]. Specifically, the cationic lipids 1,2-dioleoyl-3trimethylammonium propane (DOTAP), 1,2-di-O-octadecenyl-3-trimethylammonium propane (DOTMA) are commonly used, along with the neutral dioleoylphosphocholine (DOPC), 1,2-dioleoyl-sn-glycero-3-phosphoethanolamine (DOPE) and cholesterol [28]. Nioplexes are formed by niosomes, which are single-chain vesicles containing both non-ionic surfactants, and cationic lipids interacting with nucleic acids. Their size can vary from 10 to $3000 \mathrm{~nm}[29,30]$.

Polyplexes, lipoplexes and nioplexes do not only act as mere DNA carriers, but play an active role in modulating endocytic pathway, DNA cytoskeletal trafficking and nuclear entry [31]. To be correctly expressed, DNA molecules need to overcome several cellular barriers. The first is the cell membrane, and DNA complexes are generally internalised via clathrin-mediated, caveola-mediated endocytosis, or micro and micropinocytosis (Fig. 1). Formation of both clathrin-coated vesicles and caveolae starts with the invagination of the cell membrane and depends on dynamin activity [32]. Macro and micropinocytosis 


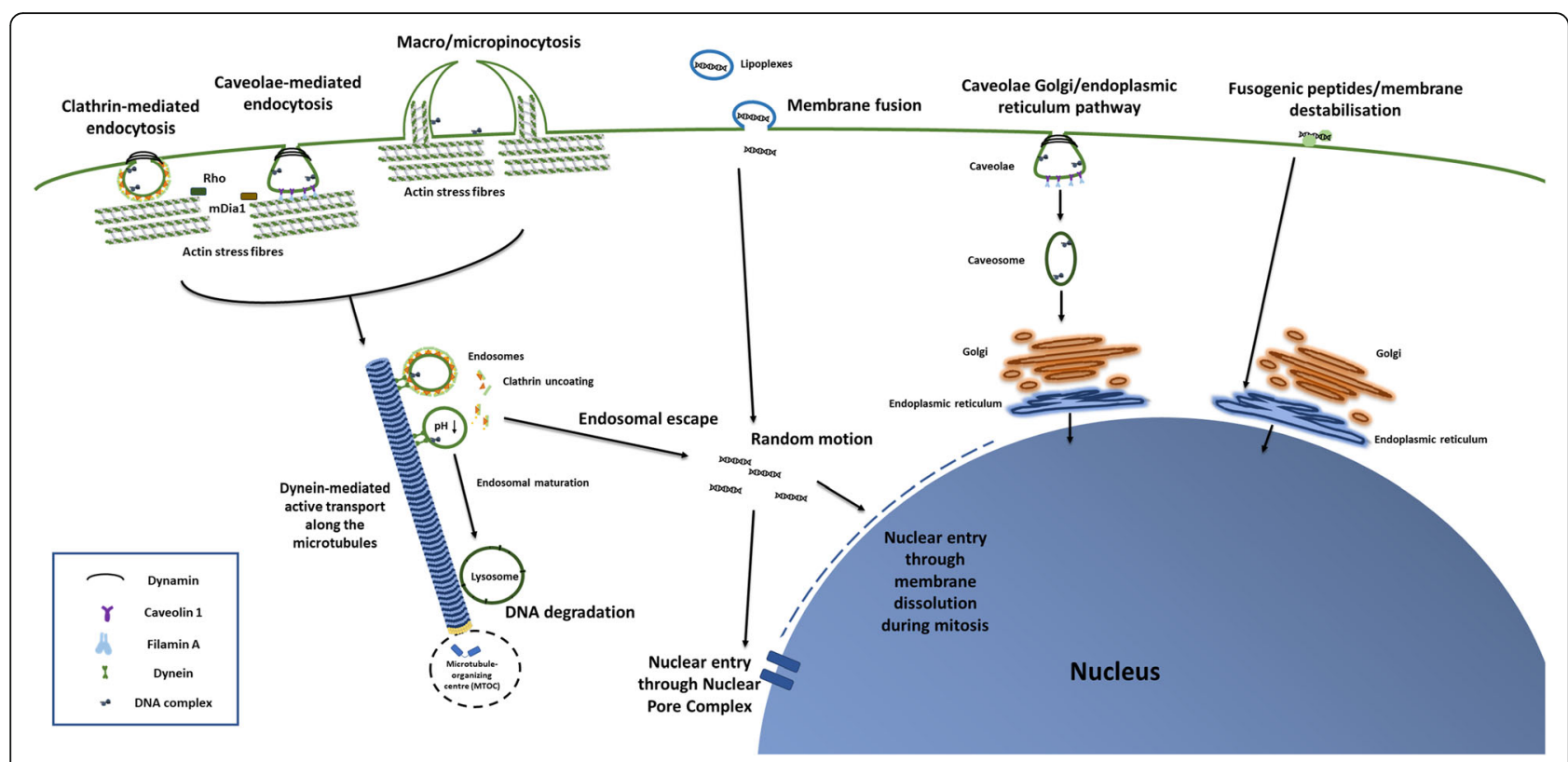

Fig. 1 Schematic representation of DNA endocytosis, cytoskeletal trafficking, and nuclear entry. Description of figure from left to right: DNA complexes enter the cells via endocytosis, through clathrin-coated vesicles, through caveolae or through pinocytosis. Their entry is regulated by Rho proteins and mDia1, which control actin dynamics. Dynamin mediates both clathrin-dependent and caveola-dependent endocytosis, whereas Caveolin 1 and Filamin A only mediate caveolae internalisation. Endocytic vesicles are transported by dynein and move along the microtubules. DNA complexes escaping the endocytic trafficking enter the nucleus. Nuclear entry either happens during cellular mitosis or through the Nuclear Pore Complex. A small portion of lipoplexes can enter the cells through direct membrane fusion. Certain caveolar vesicles were instead shown to directly target the Golgi, preventing DNA from reaching the lysosomes. Similarly, despite mechanisms being still obscure, certain CPPs can either fuse with or destabilise the plasma membrane, allowing the DNA to directly reach the Golgi-Endoplasmic Reticulum network, avoiding the lysosomal degradation [32-34].

instead, refer to the endocytosis of liquid materials and involve membrane deformations encircling the liquid. They both share common post-endocytic events [35], but the former refers to vesicles with a diameter bigger than 0.2 $\mu \mathrm{m}$, the latter to smaller ones [36].

Inhibition of clathrin-mediated route by chlorpromazine $[17,37,38]$, of caveolae using methyl- $\beta$-cyclodextrin [17], genistein [38] or filipin III [37], of micropinocytosis using amiloride or wortmannin [38] decreased transfection efficiency, to a different extent depending on complex type. In general, when cholesterol and DOPE were utilised [33], internalisation of liposomes were cholesterol sensitive [39, 40]. Liposomes containing high amount of DOTAP and DOPC might tend to interact with fluid-phase domains, rich of unsaturated lipids [33]. A small portion of lipoplexes could even enter the cells through direct membrane fusion [41, 42]. Although studies using endocytosis inhibitors provided an initial understanding of internalisation mechanisms, it is noteworthy to mention that common inhibitors may show poor specificity and their inhibitory effects are highly cell line dependant [43].

Dependence of gene transfection to different endocytic pathways also differed as a function of cell type. For instance, polyethylenimine (PEI) polyplexes were exclusively internalised via clathrin-coated vesicles by COS-7 (monkey kidney fibroblast-like cells), but by both clathrin and caveola-dependant routes by HeLa (cervical cancer cells) [37]. In HUH-7 cells (human liver cells), linear PEI was mainly internalised via the clathrindependent route, whereas branched PEI by both clathrin-dependent and caveola-dependent routes [37]. On the other hand, in A549 (adenocarcinomic human alveolar basal epithelial cells) [44], in HeLa [44] and COS-7 cells [39], liposomes were internalised by cholesterol-dependent clathrin-mediated endocytosis, whereas in CHO-7 cells through cholesterol-sensitive macropinocytosis $[40,45]$. Size of DNA complexes may also affect endocytic pathways, with for instance complexes bigger than $500 \mathrm{~nm}$ in diameter being exclusively internalised by caveola-mediated endocytosis [46].

Once internalised, DNA complexes are transported by the cytoskeleton. The actin network regulates the first steps of intracellular uptake [26], whereas microtubules are involved in the subsequent delivery from the endosomes to the lysosomes [47]. The microtubule network transports DNA complexes from the cell periphery towards the microtubule-organising centre (MTOC) (Fig. 1) [48]. Central in this context is the role of Rho, a family of small GTPases, localised at plasma membrane and at the endosomes, and associated with proteins central to actin dynamics (such as the Diaphanous-related 
formin-1 or mDia1) [49]. Rho proteins mediate the assembly and disassembly of actin stress fibres and microtubules, regulating vesicular transport [50].

Naked DNA delivery methods (e.g. electroporation or nude DNA injection/transfection) may not rely on endocytosis, but do rely on cytoskeletal transport [51]. For instance, after electroporation, actin patches colocalised with DNA at the plasma membrane, and disruption of microfilaments (i.e. polymers of actin) reduced DNA internalisation in CHO-7 cells [52]. Subsequent movement of naked DNA along microtubules was mediated by dynein [51], and followed the classical endosomallysosomal route [53].

Only few DNA molecules escape the endosomes before lysosomal degradation (Fig. 1). Disruption of actin filaments [54] and of the endosomal membrane [55] facilitated their escape, eventually increasing transfection of the human $\mathrm{T}$ leukaemia cell line (Jurkat) through carbonate apatite particles [54] and of the cell line A549 through liposomes [55].

Among mechanisms to escape endosomes, lipoplexes can directly fuse with endosome membranes, a process which is enhanced by the lipid DOPE [28, 33]. Despite the underlying mechanism being unclear, ability of Lipofectamine $^{\mathrm{sm}}$ to avoid active intracellular transport along cytoskeleton is perhaps responsible of its notoriously high transfection efficiency. A study showed indeed that, as opposed to lipoplexes composed of DOTAP and DOPC, Lipofectamine ${ }^{\mathrm{Tx}}$ exclusively moved within the cytoplasm by free Brownian diffusion [56]. Chargereversal amphiphiles 1 are also able to escape the lysosomes: the terminal ester of the lipid is hydrolysed, its charge is reversed from +1 to -1 and thereby the DNA is released and reaches the cytoplasm [45].

On the other hand, polyplexes with high buffering capacity such as PEI and polyamidoamine (PAMAM) exploit the so called 'proton sponge effect', to escape endosomes [57-59]. This is a phenomenon whereby, when endosomal $\mathrm{pH}$ lowers, cationic polymers become protonated, causing diffusion of water into the endosome. Eventually, the osmotic pressure makes the endosome swell. This-combined with the swelling of the polymer itself (due to internal electrostatic repulsion of protonated amine groups)-is sufficient to disrupt the membrane, resulting in the escape of nucleic acid into the cytoplasm [60]. Proton sponge can be enhanced by chemical modification of the polymer [61, 62]. Furthermore, highly charged polyplexes (e.g. PEI) can closely interact with the endosomal membrane, induce the formation of pores and destabilise the lipid bilayer. This membrane destabilisation would assist the proton sponge effect [60]. Nevertheless, the proton sponge effect is still not well understood, nor is it clear to which extend it contributes to lysosomal escape [63]. It was for instance hypothesised that cationic polymers cause an influx of protons and of chloride ions [64, 65]: this however, was disproved by experimental data [66, 67]. Similarly, the addition of ammine groups to poly(2dimethylaminoethyl)-methacrylate) (pDMAEMA) which increases buffer capacity and theoretically enhances the proton sponge effect-decreased in fact transfection efficiency [68]. On the contrary, acetylation of PEI (which decreases buffer capacity), enhanced gene delivery [69].

Certain cell-penetrating peptides (CPPs) allow endosomal escape, by inducing budding of vesicles from the endosomal membranes, which collapse in the cytoplasm [70].

Once in the cytoplasm, DNA complexes follow a random motion [33] and finally enter the nucleus either passively, during cell division [59] or via the nuclear pore complexes (NPC) [71]. Efficiency of the former mainly depends on the cell cycle stage at the time of transfection [72]. Attempts to improve the inclusion of DNA in the nuclei of the daughter cells relied on either the addition of targeting peptides which bind chromatin or on the incorporation of phosphorylation responsive peptides, which specifically release the DNA during mitosis [73]. However, efficiency of such systems is still controversial [74].

On the other hand, despite the exact mechanism for translocation through the NPC being still largely obscure [71], efficiency of NPC-mediated internalisation can be enhanced, by optimising composition of polyplexes/lipoplexes. For instance, when complexes were injected into cell cytoplasm, PEI, and to a lesser extent polylysine (PLL), increased nuclear transport, compared to cationic lipids [75]. Similarly, in bone marrow mesenchymal stem cells (BMSCs), in spite of a lower cytoplasmic uptake, PEI polyplexes showed a higher percentage of nuclear uptake, compared to PLL [76]. In artificial Xenopus laevis nuclei, the size and the charge of PEG nanocomplexes were also proven to affect nuclear internalisation rate [77]. Similarly, after cytoplasmic injection, the supercoiled plasmid DNA form more efficiently reached the perinuclear region, than the relaxed open circular and the linearised forms [78]. Furthermore, some studies attached a peptidic nuclear localisation signal (NLS) which enables importin-mediated nuclear transport-either to the polymeric carrier, or to the DNA molecule. This approach may increase nuclear localisation: however, it did not markedly increase transgene expression. This probably happened, because the NLS blocked the transcription of the reporter gene or it induced aggregation of the DNA with cellular structures [71]. Among systems mimicking viral entry systems, addition of the protein transduction domain (PTD) of the Tat protein of the HIV also facilitated DNA entering to the nucleus $[79,80]$. 
It is worth mentioning the existence of an alternative internalisation route, mediated by caveolae, whereby the DNA complexes do not reach the endocytic network, but the Golgi [44, 81-83]. Addition of the histone H3 peptide tail in DNA polyplexes enhanced this route [83]. However, no consensus has been reached in the scientific community on whether all [81, 84] or only specialised subsets $[85,86]$ of caveola-derived endosomes follow this route. Similarly, despite their mechanisms of internalisation being still largely obscure $[87,88]$, certain CPPs specifically target the endoplasmic reticulum (ER) close to the nucleus. For instance, lipoplexes, conjugated with the pardaxin (i.e. a single polypeptide chain composed of 33 amino acids) avoided the endosomal network $[57,89]$. From the ER, DNA can easily enter the nucleus [57], as the membranes of the two organelles are continuous [90].

Understanding the processes regulating gene transport along the cytoplasm is fundamental to develop tailored gene delivery strategies. For instance, strategies enhancing caveola-mediated endocytosis may avoid the lysosomal degradation, increasing transfection yield [81]. Endocytic pathways differs as a function of dimensionality, with 3D systems being generally associated with increase in caveola-mediated endocytosis. In one study, jetPEI ${ }^{\bullet}$ polyplexes (Polyplus-transfection ${ }^{\odot} \mathrm{SA}$ ) were internalised via caveolae and micropinocytosis by cells grown on microporous annealed particle (MAP) 3D hydrogels, but exclusively via clathrin-endocytic pathways, by cells seeded on plastic tissue dishes (2D cultures). Such differences were attributable to activation of distinct Rho proteins, with for instance Rac and Cdc42 being more integral to gene transfer, when cells were grown on the hydrogels [91]. Also addition of collagen-mimetic peptides to PEI polyplexes immobilised on collagen scaffolds, activated a specific endocytic pathway, mediated by the collagen, and involving the caveolae [92]. Furthermore, increase in the expression of RhoA, in caveola-mediated endocytosis and in polyplex-mediated transfection efficiency was reported for rat adipose-derived stem cells (ADSCs) cultured on hyaluronic acid (HA)-chitosan surfaces (and to a lesser extent on unconjugated chitosan surfaces), compared to cells on tissue plastic dishes [93].

Processes altering the cytoskeleton, such as cell encapsulation, cell spreading, adhesion, or mechanical loading further mediate DNA cellular trafficking. Understanding these mechanisms can allow to divert cell adhesion processes and cytoskeletal dynamics, in an effort to increase transgene expression [26]. Strategies described and their outcomes are discussed in the following paragraphs.

\section{DNA immobilisation and encapsulation in 3D scaffolds}

Both 2D and 3D biomaterials are largely used for gene delivery purposes. 3D scaffolds are generally fabricated thorough DNA encapsulation or immobilisation, whereas SMD utilises DNA-coated 2D materials. (Fig. 2) Addition of physical and mechanical cues (e.g. mild mechanical loading, optimal biomaterial stiffness and extracellular matrix cues) may further enhance gene delivery. (Fig. 2) With respect to the fabrication of 3D scaffolds, encapsulation refers to the entrapment of DNA complexes within the biomaterials, whereas immobilisation requires interaction between the vectors and the biomaterial. In the latter case, since the DNA is

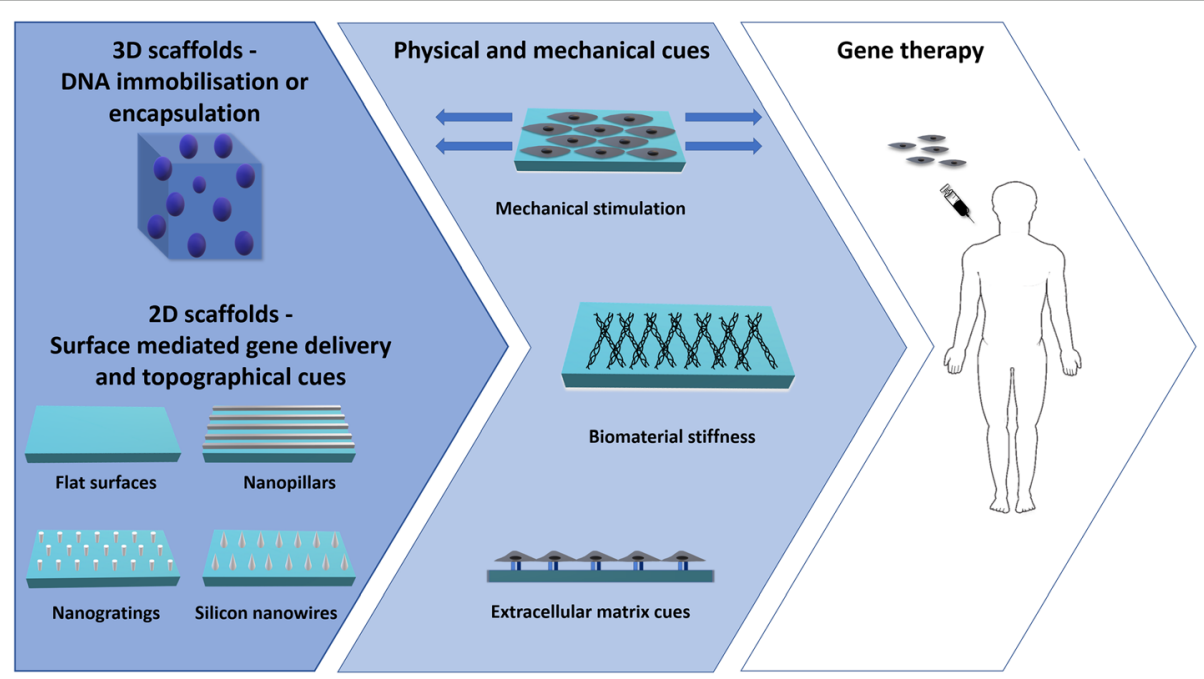

Fig. 2 Schematic representation of biomaterial-mediated gene delivery systems. DNA can be incapsulated/immobilised into 3D biomaterials or coated on 2D substrates (SMD). 2D materials may be flat, or contain topographical cues, such as nanopillars, nanogratings or silicon nanowires. Physical and mechanical cues (i.e. mechanical stimulation, optimal biomaterial stiffness and ECM cues) may further enhance transfection efficiency. Addition of ECM mimetics may even allow cell type-specific transfection 
physically attached, its mobility is reduced [23, 94]. DNA is thereby released, gradually with biomaterial degradation/cellular infiltration [15, 95], or-depending on fabrication parameters-in response to specific stimuli (e.g. variation in the $\mathrm{pH}$, salt concentration or electrochemical and thermal triggers) [96].

For immobilisation, the 3D biomaterial can either be first synthesised, and DNA only added in the final steps (to avoid exposure to potential harsh processing steps) (i.e. surface immobilisation) $[97,98]$ or can be mixed with the DNA prior to polymerisation [92].

Microporous scaffolds, with pores on the order of tens to hundreds of microns, have been largely used [97, 99102], and compared to non-porous biomaterials they facilitated cell infiltration [99, 100, 102] DNA diffusion and release [99], eventually increasing [100, 101] and prolonging [100] transgene expression. Porous material may also result in more biodegradable, than non-porous ones [99, 101]. Different DNA encapsulation techniques on oligo (polyethylene glycol) fumarate (OPF) hydrogels [103], alginate [104], polyethylene glycol (PEG) [105, 106], hyaluronic acid [99], fibrin [107], PLGA [23, 108] or gelatin [109] hydrogels were described. Similarly, immobilisation on polyacrylamide [110], cationised gelatin hydrogels [111], poly(beta-amino ester)(PBE)/ PLGA microparticles [112] and PLGA biomaterials [113], on polydopamine (PD) conjugated materials [114] and of collagen-mimetic peptides - conjugated polyplexes [115] were performed. Enzyme-responsive gene delivery systems furthermore allowed temporal control of DNA release and were fabricated by incorporating the matrix metalloproteinase (MMP) susceptible peptides GPQGIWGQ [116] and the GCRDGPQGIWGQDRCG [117, 118] into an $\mathrm{Au}$ surface [116], into a breath figure porous structures [117] or in PEG hydrogels [118]. By using similar approaches, $\mathrm{pH}$-sensitive $[119,120]$, thermosensitive $[120,121]$ or even ultrasound-activated [122, 123], visible-light assisted [124], photothermal-assisted [125] gene delivery systems were developed.

The main parameters affecting nucleic acid release are the biomaterial degradation rate, the size and amount of the DNA complexes and their interaction with the biomaterial.

Not only does degradation rate influence cell infiltration, but it also modulates temporal pattern of DNA release $[98,126]$. Biomaterials degrade over time, gradually releasing the DNA $[16,126,127]$, with totality of complexes being released after complete degradation [15]. The peak in the expression of the transgene is generally observed after complete degradation of the biomaterial, yet transgene expression in vitro [128] and in vivo [23] was maintained after several weeks. The amount of time needed to achieve complete degradation obviously varied depending on fabrication method and eventual crosslinking [127-129]. Slow degradation rate may reduce transfection efficiency at earlier timepoint [15], but extend temporal pattern or DNA release [130]. For instance, PLGA scaffolds fabricated using supercritical $\mathrm{CO}_{2}$ gas were more stable than that prepared with highpressure $\mathrm{CO}_{2}$. They allowed the release of $50 \%$ of DNA after 60 days, and in vivo transgene expression was detected even at longer timepoints [130].

On the other hand, the size of DNA complexes affects their diffusion within the biomaterial. For instance, one study prepared $4 \mathrm{KDa}$ PEI polyplexes with an average size of $142 \mathrm{~nm}, 40-\mathrm{kDa}$ PEI polyplexes with a size of $243 \mathrm{~nm}$ and Lipofectamine ${ }^{\text {tu }}$ lipoplexes with a size of $342 \mathrm{~nm}$. The larger the complexes, the slower the diffusion within the gels [109]. Similarly, naked DNA molecules are better diffused within HA/PEG hydrogels, compared to DNA/PEI complexes, probably due to their smaller hydrodynamic diameter [131]. The amount of plasmid loaded also plays a key role in regulating transgene expression. PLGA matrices loaded with $1.6 \mu \mathrm{g} / \mu \mathrm{L}$ showed higher transfection efficiency, than that loaded with $1 \mu \mathrm{g} / \mu \mathrm{L}$. After subcutaneous implantation into mice, transgene expression was detectable even after 126 days [22]. Similarly, fibrin hydrogels loaded with $2 \mu \mathrm{g}$ of DNA showed higher transgene expression, compared to hydrogels loaded with 0.1 $\mu \mathrm{g}$ [18]. Yet, loading high DNA concentration can be technically difficult, due to its tendency to aggregate [132], which may even compromise cellular transfection [18]. Addition of neutral saccharides (e.g. sucrose) [105], polysaccharides (e.g. agarose) [107], PEG-modification of polyplexes [106], optimisation of physical properties (size, polydispersity, zeta potential) of complexes [126], can mitigate charge-charge interactions, reducing aggregation tendency. Surface immobilisation could also mitigate polyplex aggregation tendency. One study fabricated HA hydrogel, where PEI/DNA polyplexes were either encapsulated (the complexes were mixed to polymers, prior to polymerisation) or immobilised (DNA complexes were bound to polymerised hydrogels, via electrostatic interaction). The latter resulted in a more homogenous distribution of the plasmid and led to higher transgene expression levels [106]. Similarly, compared to encapsulation, surface immobilisation of PEI complexes in fibrin hydrogels led to a higher transfection and to a faster release. Through surface immobilisation, the DNA was homogeneously exposed to the surface of the biomaterial and was easily accessible by the cells. After encapsulation, the DNA was distributed instead through the gels in larger and possibly aggregated structures. Its exposure was dependent on cell-mediated degradation [127]. However, it is noteworthy to mention a reduction in cellular viability at early timepoints, for surface immobilisation, compared to encapsulation [127]. 
Finally, enhancing interactions between biomaterial and DNA complex could increase the extent and duration of gene transfer. For instance, incorporation of collagen-mimetic peptides into PEI polyplexes, by increasing interaction with carrier collagen hydrogels, prolonged DNA release [92]. In one study, PLGA microspheres were surface-modified with PEI, PLL, poly(allylamine hydrochloride) (PAH), polydiallyldimethylammonium (PDDA), or PD. [133] The latter-by increasing strength of immobilisation [114]-prolonged the pattern of DNA release from 5 days (of unmodified control microspheres) to 15 days [133].

By understanding how each of these parameters affects cellular transfection, temporal patterning of transgene expression can be tailored, eventually meeting the demands of various applications.

\section{Surface-mediated gene delivery}

SMD is an emerging approach, relying on 2D surfaces, whereby DNA complexes are immobilised to a substrate via covalent attachment or non-specific adsorption [134]. Not only does SMD allow to better control localisation of transfected cells, but-by optimising surface topography-it may also increase cell receptivity to transfection. (Fig. 2). When performed on tissue plastic dishes, SMD generally requires a pre-coating with serum $[27,105]$ or proteins [135], to mediate nucleic acid immobilisation. Alternatively, lipoplexes/polyplexes containing functional groups that are complementary to the substrate can be used [135]. Different substrates, such as alginate/polycaprolactone fibers [136], polydopaminecoated glass substrates [137], PEI [138], PLGA fibres [113] and polydimethylsiloxane (PDMS) films [139], were used.

The efficacy of SMD has been largely debated. One study compared SMD (serum-coated tissue culture polystyrene), with bolus delivery of PEI polyplexes. One day after transfection, the transfection efficiency of SMD was lower [27]. Another study using Lipofectamine ${ }^{\mathrm{Tm}}$ lipoplexes showed instead similar transfection efficiency between SMD and bolus delivery [27]. However, it is noteworthy to mention that whilst bolus delivery leads to a peak in gene transfection, when conjugated to biomaterials, DNA complexes are gradually released. Thereby lower amounts may be available at early timepoints, but higher transfection yield can be achieved at longer timepoints [109].

On the other hand, PEI polyplexes, incorporated at the surface of electrospun graphene oxide-incorporated PLGA nanofibrous mat, led to a higher transfection rate of human embryonic kidney cells (HEK293) and human umbilical cord-derived MSCs, compared to bolus delivery [113]. Despite a high biological variability, optimisation of a combination of ECM mimetic peptides and polysaccharides [140] could further increase transfection efficiency. Similarly, as discussed in the next paragraph, incorporation of topographical patterning may modulate DNA endocytosis and cytoskeletal trafficking.

\section{Surface topography}

2D surfaces offer the possibility to incorporate topographic cues, which are generally dominant concerning cells spreading and morphology, over biomaterial composition [141]. For instance, human MSCs cultured on $350-\mathrm{nm}$ gratings showed decreased expression of integrin subunits $\alpha 2, \alpha \mathrm{V}, \beta 2, \beta 3$ and $\beta 4$ and exhibited an aligned actin cytoskeleton, compared to unpatterned controls [142]. Human amniotic membrane-derived mesenchymal stem cells (hAM-MSCs) and mouse embryonic stem cells (mESCs) showed strong alignment on deep grooves and inhibition of spreading on nanopillars [143]. Topographical cues modulated focal adhesion kinase (FAK) activity and thereby the RhoA phosphorylation level. This was proven to mediate actin fibre arrangement and to activate different signalling pathways, including the mitogen-activated protein kinase (MAPK) cascade [144]. Lipid films with different topologies (i.e. 3D-bicontinuous cubic, 2D-inverted hexagonal, or 1D-lamellar nanostructures) also led to a distinct transfection efficiency [145]. (Table 1) Among different morphological changes induced by substrate topography (i.e. increase in cell spreading, change in nuclear volume, focal adhesions size and area and cellular deformation), the nuclear volume most closely correlated with transfection efficiency [139].

In spite of few discordances on how dimensionality regulates cytoskeletal arrangements, it is recognised that a certain degree of cell spreading enhances transfection. (Table 1) Compared to unpatterned substrates, micropatterns facilitating either spreading or elongation of MSCs promoted gene delivery, by enhancing the uptake of the cationic complexes [146]. However, extremely deep nanotopographies may decrease cell adhesion, and consequently cell spreading and nuclear volume [139, 154156], ultimately jeopardising cellular transfection [139]. C2C12 skeletal myoblasts, if grown on deep nanogrooved surfaces (400-nm and 800-nm depth), showed cytoskeletal stretching, nucleus elongation and reduced nuclear volume. They also were less efficiently transfected by PEI polyplexes, compared to superficial patterns $(50 \mathrm{~nm})$. Disruption of F-actin organisation restored nuclear morphology and transgene expression [147]. Similarly, fibroblasts on deep nanogratings and nanopillars $(560 \mathrm{~nm}$ in heights), showed smaller nuclear volumes and a reduced transfection rate, compared to cells on superficial patterns (150 nm in height) [139]. On the other hand, certain topographic cues can reduce cellular adhesion and spreading, ultimately compromising transfection 
Table 1 Surface topography and gene delivery. Research papers assessing the effect of different surface topographies on surfacemediated non-viral gene delivery

\begin{tabular}{|c|c|c|c|c|}
\hline Biomaterial & Cell type & $\begin{array}{l}\text { Transfection } \\
\text { system }\end{array}$ & Change in transfection efficiency & Ref. \\
\hline $\begin{array}{l}\text { Coverslips coated with a lipid film, having } \\
\text { 3D-bicontinuous cubic, 2D-inverted hex- } \\
\text { agonal, or 1D-lamellar nanostructures }\end{array}$ & $\begin{array}{l}\text { HeLa-Luc cell line, } \\
\text { stably expressing } \\
\text { the luciferase }\end{array}$ & $\begin{array}{l}\text { siRNA directly } \\
\text { loaded into the } \\
\text { lipid film }\end{array}$ & $\begin{array}{l}\text { Luciferase activity (luminescence/mg protein) was } 4 \times \\
10^{5} \text { in the untreated control. } \\
\text { Highest gene silencing efficacy was for 3D-bicontinuous } \\
\text { phase (luciferase activity } \sim 1.5 . \times 10^{5} \text { ). } \\
\text { In 2D-hexagonal and 1D-lamellar phases, luciferase activ- } \\
\text { ity was almost } 2.5 \times 10^{5} \text {. } \\
\text { Bolus delivery (Lipofectamine }{ }^{\mathrm{TM}} \text { ) showed gene silencing } \\
\text { efficacy similar to that of 3D-bicontinuous phase. }\end{array}$ & {$[145]$} \\
\hline $\begin{array}{l}\text { Micropatterns with different diameter and } \\
\text { aspect ratio }\end{array}$ & Human MSCs & $\begin{array}{l}\text { Cationic } \\
\text { polyplexes }\end{array}$ & $\begin{array}{l}\text { Highest transfection efficiency was } 20 \% \text {, for ellipses with } \\
\text { aspect ratio } 8: 1 \text { and surface area } 80 \mu \mathrm{m} \text {. } \\
\text { Lowest transfection efficiency was } 2 \% \text {, for circular } \\
\text { micropattern with a diameter of } 20 \mu \mathrm{m} \text {. }\end{array}$ & {$[146]$} \\
\hline $\begin{array}{l}\text { Nanogrooved and nanopillar surfaces with } \\
\text { different width/diameter and height }\end{array}$ & $\begin{array}{l}\text { Normal human } \\
\text { lung fibroblasts }\end{array}$ & $\begin{array}{l}\text { Lipofectamine }^{\text {TM }} \\
2000\end{array}$ & $\begin{array}{l}\text { Highest \% of transfection was } 50 \% \text {, in grooves } 500 \mathrm{~nm} \\
\text { in width and } 150 \mathrm{~nm} \text { in height and in nanopillars with a } \\
\text { diameter of } 500 \mathrm{~nm} \text { and a width of } 150 \mathrm{~nm} \text {. } \\
\text { In flat surfaces, \% transfection was } ~ 30 \%\end{array}$ & {$[139]$} \\
\hline $\begin{array}{l}\text { Nanogrooved surfaces with different deep } \\
\text { and depth }\end{array}$ & $\begin{array}{l}\text { C2C12 skeletal } \\
\text { myoblasts }\end{array}$ & $\begin{array}{l}\text { jetPEl }^{\circledR} \\
\text { (Polyplus, US) }\end{array}$ & $\begin{array}{l}\text { Decrease of } \sim 73 \% \text { in transfection efficiency, on } \\
\text { nanogrooved patterns of } 400 \mathrm{~nm} \text { groove width and } 400 \\
\mathrm{~nm} \text { depth, compared to flat surfaces. } \\
\text { Decrease of } \sim 90 \% \text { on nanogrooved pattern of } 800 \mathrm{~nm} \\
\text { groove width and } 500 \mathrm{~nm} \text { depth, compared to flat } \\
\text { surfaces. }\end{array}$ & {$[147]$} \\
\hline Nanogratins and nanopillar surfaces & Human MSCs & $\begin{array}{l}\text { Lipofectamine }^{\text {TM }} \\
2000\end{array}$ & $\begin{array}{l}\text { Highest } \% \text { transfection was at } 3.3 \% \text {, for cells on grooves } \\
\text { of } 250 \mathrm{~nm} \text { width. In flat surfaces, } \% \text { transfection was } \\
1.8 \%\end{array}$ & {$[148]$} \\
\hline SiNWs & $\begin{array}{l}\text { Jurkat, L1.2 and } \\
\text { GPE86 }\end{array}$ & Naked DNA & $\begin{array}{l}\% \text { of transfection was } ~ 20 \%, 20 \% \text { and } 5 \% \text { in GPE86, L1.2 } \\
\text { and Jurkat respectively. } \\
\% \text { transfection was between } 0 \% \text { and } 1 \% \text {, in flat surfaces } \\
\text { for all cell types. }\end{array}$ & {$[149]$} \\
\hline SiNWs with different heights & $\begin{array}{l}\text { Human dental } \\
\text { pulp stem cells }\end{array}$ & Naked DNA & $\begin{array}{l}\% \text { transfection was } \sim 90 \% \text { for SiNW with heights of } 1.2 \\
\text { and } 3.5 \mu \mathrm{m} \text {. } \\
\% \text { transfection was less than } 10 \% \text { for SiNW with heights } \\
\text { of } 0.4 \mu \mathrm{m} \text { and } 6.3 \mu \mathrm{m} \text {. }\end{array}$ & {$[150]$} \\
\hline SiNWs & $\begin{array}{l}\text { Mouse embryonic } \\
\text { stem cells }\end{array}$ & Naked DNA & Transfection efficiency lower than $1 \%$. & {$[151]$} \\
\hline Ethanolamine-functionalised SiNWs & HeLa & Naked DNA & $\begin{array}{l}\text { Luciferase expression (luminescence/mg protein) was } \\
10^{6} \text { in ethanolamine-functionalised siNWs, compared to } \\
10^{4} \text { in non-functionalised siNWs }\end{array}$ & {$[152]$} \\
\hline Nanopillars of different diameter & $\begin{array}{l}\text { C2C12 skeletal } \\
\text { myoblasts }\end{array}$ & $\begin{array}{l}\text { jetPRIME }{ }^{\circledast} \text { or } \\
\text { Lipofectamine }^{\text {TM }}\end{array}$ & $\begin{array}{l}\text { For jetPRIME }{ }^{\circledast} \text {, luciferase expression (luminescence/mg } \\
\text { protein) was } \sim 8 \times 10^{3} \text { for pillars with a diameter of } \\
1000 \mathrm{~nm} \text {, whereas in flat surfaces it was } 3 \times 10^{3} \\
\text { For Lipofetamine }{ }^{\mathrm{TM}} \text {, luciferase expression was } 1 \times 10^{3} \text { in } \\
\text { nanopillars with a diameter } 1000 \mathrm{~nm} \text { and } 5 \times 10^{3} \text { in flat } \\
\text { surfaces. }\end{array}$ & [153] \\
\hline
\end{tabular}

efficiency. For instance, when human MSCs were seeded on poly(methyl methacrylate) (PMMA) with nanopillars (250 nm in height) and micropillar ( $2 \mu \mathrm{m}$ in height), intracellular actin-rich rings outlining the portion of the substrates in contact with the cells was visible. Yet, no such actin-rich regions were seen on nanograting topography (250 nm in height). The latter topography also correlated with the lowest transgene expression (Lipofectamine ${ }^{\mathrm{rm}}$ ) and FITC-dextran uptake [148].

A recently emerging application of SMD is the silicon nanowires (siNWAs). These penetrate the cells, without perturbing their main functions, and release surface- bound DNA complexes, directly inside the cytoplasm [157]. Compared to flat silicon substrates, siNWAs induced morphological changes in the cytoplasm and nuclei, eventually promoting endocytosis in different cell lines, including an immortalised human $\mathrm{T}$ lymphocyte cell line (Jurkat), the cellosaurus cell line L1.2 and the murine fibroblast cell line GPE86 [149]. Transfection efficiency was governed by the nanowire geometry (in terms of diameter, length and density of the nanowires), but also varied according to cell type, with for instance HeLa cells showing significantly lower transfection efficiency (7-9\%), compared to HEK293 (85-86\%), human 
primary fibroblasts $(61 \%)$ and dental pulp stem cells (85-88\%) [150]. In murine embryonic stem cells-derived cardiac myocytes, reported transfection efficiency was even lower than 1\% [151]. Yet, transfection could be increased by surface modification with high-molecularweight branched PEI [158], or via chemical modification of the siNWAs (e.g. ethanolamine functionalisation of siNWAs) [152] and of the polyplexes (e.g. addition of low concentration of $\mathrm{Zn}^{2+}$ on calcium nanoparticles) [152]. Furthermore, one study demonstrated a dependence of SMD-mediated transfection on DNA complex type. This study prepared nanopillars with different diameters $(200-1000 \mathrm{~nm})$ and depths (200 or $400 \mathrm{~nm})$, where cells were seeded and transfected with either the polyplex jetPRIME ${ }^{\oplus}$ or Lipofectamine ${ }^{\text {тx }}$. It identified two main cell cytoskeletal morphologies after transfection, based on the presence or absence of a perinuclear actin cap (pnAC) in the F-actin. Compared to cells on flat surfaces or on shallow nanopillars, cells on the nanopillars were smaller, less spread, had shorter F-actin filaments, and a lower percentage of pnAC. They showed a significantly lower transfection efficiency with Lipofectamine ${ }^{\mathrm{Tw}}$, but a higher transfection rate with jetPRIME ${ }^{\bullet}$ [153]. However, as mechanisms of internalisation and nuclear transport of jetPRIME ${ }^{\bullet}$ polyplexes are not known, the difference in transfection efficiency is difficult to explain.

\section{ECM cues}

Early steps of transfection require non-specific binding of cationic DNA complexes with negatively charged molecules at the cell surface, such as the heparan sulphate proteoglycans [26]. Despite this ability being traditionally considered exclusive of viruses, by either modifying composition of complexes [159] or of carrier biomaterials [160-163], it is possible to selectively transfect certain cell types [1]. With respect to modifications on DNA complexes, conjugation with HA facilitated transfection of cells overexpressing the CD44 [28], conjugation of niosomes with transferrin allowed their internalised by transferrin receptor-mediated endocytosis [164], whilst coating of DNA polyplexes with poly- $\gamma$ glutamic acid ( $\gamma$-PGA) allowed specific binding to the tumour-associated gamma-glutamyl transpeptidase (GGT) [165]. DNA nanoplexes containing heparin or folic acid PEI derivatives in vitro led to higher transfection efficiency and lower toxicity compared to unmodified PEI [166]. Electrostatic association of nanocrystals of carbonate apatite with fibronectin and/or E-cadherinFc accelerated transgene delivery in a human $\mathrm{T}$ leukaemia cell line (Jurkat) [54]. Furthermore, one study prepared folate-decorated triblock copolymer delivering siRNA [167], and showed selective transfection of the cell line SKOV-3 cells overexpressing the folate receptor- $\alpha(F R \alpha)$, over the cell line A549, which only had a basal FR $\alpha$ expression. Similarly, after the addition of a $\mathrm{N}$-acetylglucosamine ligand to polymeric nanoparticles, vimentin-expressing cells were more efficiently transfected compared to non-expressing cells, due to a specific polyplex receptor-mediated endocytosis [168].

On the other hand, ECM-derived adhesion peptides, protein fragments, or native proteins can be conjugated to biomaterials, promoting cellular adhesion, and ultimately gene delivery. Different peptides have been used, and some of them may even allow selective transfection of cells expressing specific integrins/membrane receptors (Table 2). The tri-amino acid sequence arginine-glycineaspartate (RGD), naturally found in collagen and fibronectin and recognised by nearly half of the integrins [184] has been widely utilised (Table 3). In NIH/3T3 cells, Ti substrates with a poly(acrylic) acid (PAA) brush, modified with RGD, showed the highest transfection efficiency, compared to flat Ti surfaces, to PAA brushes modified with a control peptide (RGE) and to unmodified PAA [163]. TransFast ${ }^{\text {tw }}$-mediated transfection of NIH3T3 murine fibroblasts was increased by conjugation of PEG hydrogels with RGD peptides [162] and jet$\mathrm{PEI}^{\circ}$ polyplex-mediated transfection of human dermal fibroblasts was increased by conjugation of MAP hydrogels with RGD peptides [185].

Different natural biomaterials, including collagen [14] and fibronectin [187], were also used. Among fibronectin fragments, the ones preferentially activating the $\alpha 3$ / $\alpha 5 \beta 1$ over the $\alpha \mathrm{v} \beta 3$ led to significantly higher transfection, in spite of a lower cell spreading [185]. In one study, surfaces coated with fibronectin, with ECM gels or with collagen IV increased murine MSC spreading and transfection efficiency, compared to uncoated surfaces. Interestingly, despite showing the highest level of polyplex internalisation, surfaces coated with collagen I decreased transfection efficiency [160]. This was attributable to reduced intracellular trafficking of the internalised complexes. Indeed, interaction with fibronectinbut not with collagen I-activated the Rho proteins RhoA, Cdc42 and Rac1. On the contrary, inactivation of Rho decreased transgene expression in fibronectincoated surfaces, by more than $90 \%$ [187].

Addition of cell ligands over a certain threshold may not lead to any additional positive effect: rather an optimal intermediate concentration needs to be found. For instance, hyaluronic acid hydrogels functionalised with $100 \mu \mathrm{M}$ of RGD peptides led to higher transfection efficiency, than hydrogels functionalised with $10 \mu \mathrm{M}$ and $400 \mu \mathrm{M}$ [161]. Similarly, fibrinogen concentration of 25 $\mathrm{mg} / \mathrm{mL}$ was more efficient than concentrations of 10 or $50 \mathrm{mg} / \mathrm{mL}$ [18].

However, ECM is involved in several processes, such as cell adhesion, spreading, internalisation of DNA and even cytoplasmic transport. Thereby, assessing the effect 
Table 2 ECM-derived cell adhesion peptides. Most used peptides derived from ECM proteins and targeting specific cell types/cell receptors

\begin{tabular}{|c|c|}
\hline Peptide & Specificity \\
\hline $\begin{array}{l}\text { Modified fibronectin (either a Leu-Pro point mutation at position } 1408\left(9^{*} 10\right) \text { or a labile } 4 \times \\
\text { Gly linker }(9(4 G) 10) \text { between the ninth and tenth domain domains }\end{array}$ & Integrin a3/a5 $\beta 1$ or av $\beta 3$ [169] \\
\hline RGDS sequence from fibronectin & Integrin av $\beta 3$ [170] \\
\hline REDV sequence from fibronectin & Integrin a $4 \beta 1$ of endothelial cells [171] \\
\hline LDV sequence from fibronectin & Integrin a $4 \beta 1$ [172] \\
\hline cRGDfK, cRGDyK and RGDC4 CACRGDMFGCA cyclic peptides from collagen & Integrins av $\beta 3$ [173] and av $\beta 5$ [84] \\
\hline GGYGGGP(GPP)5GFOGER(GPP)5GPC sequence from collagen & $\begin{array}{l}\text { Integrin a2 } \beta 1 \text {, which is expressed by osteoblasts and } \\
\text { MSCs during osteogenesis [174] }\end{array}$ \\
\hline GFOGER sequence from collagen & $\begin{array}{l}\text { Collagen receptors (integrins } \alpha 1 \beta 1, a 2 \beta 1, a 10 \beta 1 \text { and } \\
\text { a11 } 11 \text { ) [174-177] }\end{array}$ \\
\hline PDGEA sequence from collagen type I & $a 2 \beta 1$ in osteoblasts [178] \\
\hline PGRGDS sequence from osteopontin & avß3 in osteoblasts [178] \\
\hline DFKLFAVYIKYR-GGC (C16Y) sequence from the mouse laminin & $\begin{array}{l}\text { Integrins av } \beta 3 \text { and a5 } \beta 1[179] \text {, typical of endothelial } \\
\text { cells }\end{array}$ \\
\hline IKVAV sequence from laminin & $\begin{array}{l}\text { Integrin } \beta 1[180] \text { ( } \alpha 3 \beta 1 \text { and } a 6 \beta 1 \text { [84] and a4 } \beta 1) \text { [181], } \\
\text { with high affinity for neuronal cells }\end{array}$ \\
\hline RKRLQVQLSIRT (AG73) sequence from laminin & Syndecan-2 [182] \\
\hline VAPG sequence from elastin & $\begin{array}{l}\text { It binds to smooth muscle cells and it is not specific to } \\
\text { integrins [183] }\end{array}$ \\
\hline RRETAWA synthetic peptide & Integrin a5 $\beta 1[181]$ \\
\hline
\end{tabular}

of ECM mimetic results is challenging. Furthermore, scaffolds with different amounts of cell adhesion ligands may also have different stiffness, allowing a different DNA diffusion, DNA release or cellular infiltration. A certain variability can also be observed depending on cell type, with a study showing that different concentrations of fibrinogen were needed to transfect murine fibroblasts or human embryonic kidney [15]. Finally, the seeding approach (i.e. whether cells are embedded or seeded on top of hydrogels) also modulated the effect of ECM cues [15].

\section{Biomaterial stiffness}

In spite of having traditionally been only investigated for its structural and mechanical role, biomaterial stiffness has recently emerged as a key regulator of several cellular processes, including transfection. (Table 4) The most evident effect is related to biomaterial stability, water content, swelling ratio and thereby DNA diffusion and release [111]. Furthermore, be they seeded on a substrate [192, 193] or embedded in 3D structures [9, 188], cells respond to variable stiffness by rearranging their cytoskeleton. Increased substrate stiffness caused reinforcement and acquisition of orientational order of actin stress fibers [190, 193], which in turn influence cell polarity and cell shape [192]. Actin fibres furthermore colocalise with caveolae and regulate endocytosis [34]. Stiffer matrices also activated $\beta 1$-integrin $[194,195]$ and FAK $[188,190,194-196]$, which are involved in contractile force $[194,195]$. It was also reported a correlation between substrate stiffness and expression of RhoA [197], which is the main regulator of stress fibres [34], and is involved in polyplex transport within the cytoplasm [93, 187]. Differences in cell morphology and actin cytoskeletal rearrangement could be observed even when comparing cells seeded on tissue plastic dishes, or on the softer substrate polydimethylsiloxane (PDMS) [142]. By further varying concentrations of a curing agent, a study fabricated PDMS substrates with variable stiffness (from $50 \mathrm{kPa}$ to $1 \mathrm{MPa}$ ), to grow murine chondrocytes [197, 198]. It showed that lower stiffness correlated with reduced intercellular connections and gap junctions, reduced cell area and absence of highly organised paralleled actin fibres [198].

Biomaterials with tuneable stiffness are generally prepared by either crosslinking the polymer or by varying its concentration. However, if natural biomaterials are used, the former approach may reduce the number of available cell-binding sites [199-201], whereas the latter alters the cell ligand density. Thus, inert polymers can be mixed with natural, or RGD-functionalised ones [202]. For instance, hydrogels containing alginate (i.e. inert component) and collagen can be used. Alginate self-polymerises after the addition of calcium carbonate [9]: by varying the concentration of the latter, stiffness can be controlled [202].

Cells can be either seeded on top of substrates or encapsulated in gels of different stiffness. In the first case, higher stiffness generally correlated with increased 
Table 3 ECM cues and gene delivery. Research papers assessing the effect of ECM cues on biomaterial-mediated gene delivery

Biomaterial Cell type Transfection Change in transfection efficiency Ref.

Titanium substrates, modified with RGD-functionalised PAA brushes (N/P ratio of 20)

Fibrin hydrogels functionalised with PEG-RGD peptides

Collagen-l-alginate hydrogels, with different collagen: alginate ratios

MAP hyaluronic acid hydrogels functionalised with RGD peptides.

Collagen I, fibronectin, laminin, collagen IV, vitronectin or ECM gel coated plates

Denatured or native collagenPLGA composite vascular stents

A10 murine vascular smooth muscle cell line

Fibrin hydrogels, prepared with different concentrations of fibrinogen

Hyaluronic acid hydrogels functionalised with RGD peptides

HT-1080 human

\section{Human BMSCs}

Murine MSCs

Murine MSCs
NIH3T3 murine fibroblasts fibrosarcoma cell line and $\mathrm{NIH} 3 \mathrm{~T} 3$ murine fibroblasts

Human dermal fibroblasts system

PEl polyplexes

Lipoplexes

In RGD-functionalised PAA brushes, lucif
minescence/mg protein) was $2.5 \times 10^{8}$. In non-functionalised PAA brushes, it was $\sim 7 \times 10^{6}$.

pression (luminescence/well/day) was $\sim 10^{4}$, whereas in pression (luminescence/well/day) was $\sim 1$
non-functionalised hydrogels it was $\sim 10^{3}$ For NIH3T3, in RGD-functionalised hydrogels, luciferase expression (luminescence/well/day) was $\sim 10^{4}$, whereas in non-functionalised hydrogels it was less than $10^{1}$.

$$
\begin{array}{ll}
\text { 3D-FectIN }{ }^{T M} & \text { Decreasing the collagen: alginate ratio from 1:1 to 1:2 } \\
(\mathrm{OZ} & \text { decreased transgene expression 1000-fold. }
\end{array}
$$$$
\text { Biosciences) }
$$

jetPEI ${ }^{\circledast}$

High RGD clustering ratio (500 and $100 \mu \mathrm{M}$ ), resulted in a cumulative luciferase expression (luminescence) higher than $2 \times 10^{7}$.

Low RGD clustering ratio (100 and $250 \mu \mathrm{M}$ ) resulted in a cumulative luciferase expression of $1 \times 10^{7}$.

Highest luciferase expression (luminescence/mg protein) was $7 \times 10^{8}$, in fibronectin-coated plates. Lowest luciferase expression was $2 \times 10^{6}$ in collagen Icoated plates.

In uncoated plates, luciferase expression was $4 \times 10^{7}$.

Lipofectamine $^{\mathrm{TM}}$ Number of transfected cells per 200x field was $\sim 1$ for native collagen and almost 20 for denatured collagen. Supplementation of tenascin- $\mathrm{C}$ in native collagen substrates increased transfection, with number of transfected cells per 200x field being $\sim 14$.

NIH3T3 murine fibroblasts Lipoplexes Highest luciferase expression (luminescence/10 4 cells) was 550 for concentrations of $25 \mathrm{mg} / \mathrm{mL}$. Lowest expression was 200 , for fibrinogen concentrations of $50 \mathrm{mg} / \mathrm{mL}$.

PEl polyplexes

RGD concentration of $100 \mu \mathrm{M}$ resulted in a cumulative luciferase expression (luminescence) $\sim 6 \times 10^{5}$.

RGD concentrations of $10 \mu \mathrm{M}$ and $400 \mu \mathrm{M}$ resulted in a cumulative luciferase expression (luminescence) $\sim 4.5 \times 10^{5}$

Ref.

[163]

[162]

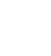


Table 4 Biomaterial stiffness and gene delivery. Research papers assessing the effect of biomaterial stiffness on non-viral-mediated gene delivery

\begin{tabular}{|c|c|c|c|c|}
\hline Biomaterial & Cell type & $\begin{array}{l}\text { Transfection } \\
\text { system }\end{array}$ & Change in transfection efficiency & Ref. \\
\hline $\begin{array}{l}\text { MAP hyaluronic acid hydrogels } \\
\text { of different stiffness }\end{array}$ & Human dermal fibroblasts & jetPEI ${ }^{\circledast}$ & $\begin{array}{l}\text { Stiffer hydrogels resulted in a cumulative transgene } \\
\text { expression (luminescence) of } 2 \times 10^{7} \text {. } \\
\text { Softer hydrogels resulted in a cumulative transgene } \\
\text { expression (luminescence) of } 1 \times 10^{7} \text {. }\end{array}$ & {$[185]$} \\
\hline $\begin{array}{l}\text { PLGA porous scaffolds of } \\
\text { different stiffness }\end{array}$ & Human ADSCs & $\begin{array}{l}\text { Chitosan } \\
\text { polyplexes }\end{array}$ & $\begin{array}{l}\text { Transgene expression was 2-fold higher in stiffer scaffolds, } \\
\text { compared to soft ones. }\end{array}$ & [188] \\
\hline $\begin{array}{l}\text { Alginate gels of different } \\
\text { stiffness, conjugated with RGDSP } \\
\text { peptides substrates }\end{array}$ & murine preosteoblasts & PEl polyplexes & $\begin{array}{l}\text { Transgene expression } 4 \text { times higher in stiffer substrates } \\
\text { compared to soft ones. }\end{array}$ & [189] \\
\hline $\begin{array}{l}\text { Gelatin-coated silicone hydrogels } \\
\text { of different stiffness }\end{array}$ & Human ADSCs & $\begin{array}{l}\text { Nanolipoplexes } \\
\text { added in the } \\
\text { culture medium }\end{array}$ & $\begin{array}{l}\text { Nanolipoplexes were more efficiently internalised in stiffer } \\
\text { substrates ( } 70 \text { ng internalised per stiff scaffold, compared } \\
\text { to } 60 \mathrm{ng} \text { per soft scaffolds) }\end{array}$ & [190] \\
\hline $\begin{array}{l}\text { PEGDA hydrogels of different } \\
\text { stiffness }\end{array}$ & $\begin{array}{l}\text { NIH3T3 murine fibroblasts, } \\
\text { BMSCs, and C2C12 } \\
\text { skeletal myoblasts }\end{array}$ & PEI polyplexes & $\begin{array}{l}\text { Stiffer hydrogels led to higher transgene production: } \\
700 \text { ng in stiff hydrogels and } 400 \text { ng in soft hydrogels, for } \\
\text { fibroblasts. } \\
200 \mathrm{ng} \text { in stiff hydrogels and } 100 \mathrm{ng} \text { in soft hydrogels, for } \\
\text { BMSCs. } \\
100 \mathrm{ng} \text { in stiff hydrogels and } \sim 50 \mathrm{ng} \text { in soft hydrogels, for } \\
\text { C2C21 }\end{array}$ & [191] \\
\hline $\begin{array}{l}\text { Hyaluronic acid hydrogels of } \\
\text { different stiffness }\end{array}$ & Murine MSCs & PEl polyplexes & $\begin{array}{l}\text { Soft hydrogels led to a higher transgene expression } \\
\text { (luminescence } \sim 5 \times 10^{5} \text { ), compared to stiff ones } \\
\text { (luminescence } \sim 1 \times 10^{5} \text { ) }\end{array}$ & [161] \\
\hline $\begin{array}{l}\text { 3D collagen-l-alginate hydrogels, } \\
\text { of different stiffness and colla- } \\
\text { gen: alginate ratios }\end{array}$ & Human BMSCs & $\begin{array}{l}\text { 3D-FectIN }{ }^{\mathrm{TM}}(\mathrm{OZ} \\
\text { Biosciences) }\end{array}$ & $\begin{array}{l}\text { Stiff hydrogels led to a } 5,000 \text {-fold increase in transgene } \\
\text { expression, compared to cells transfected using } 2 D \\
\text { systems. } \\
\text { At collagen: alginate ratio }(1: 2) \text {, transgene expression in } \\
\text { stiff hydrogels was } 20 \text {-fold higher, than in soft ones. }\end{array}$ & [14] \\
\hline
\end{tabular}

could be that high stiffness also resulted in longer degradation rates, DNA release profiles and distinct transgene expression kinetics. Furthermore, stiffer hydrogels may limit cellular infiltration and migration, yet transfected cells are predominantly the ones migrating within the biomaterial [162]. Clathrin-mediated vesicles are indeed implicated in cell migration $[12,13]$, with an increased rate of endocytosis at the trailing edge, away from the lagging edge [205]. Additionally, excessive tension, resulting from substrates with high stiffness [206], might alter and stall clathrin-mediated endocytosis [207, 208]. Having said this, no clear consensus has, in fact, been reached as yet: in one study, stiff collagen I /alginate hydrogels (storage modulus of $1500 \mathrm{~Pa}$ ) led to a transfection efficacy of encapsulated human MSCs, ten times higher than soft ones (150 Pa) [14]. Another study, although did not measure the modulus, found that intermediate concentrations of fibrinogen $(25 \mathrm{mg} / \mathrm{mL}$, compared to 10 or $50 \mathrm{mg} / \mathrm{mL}$ ) led to higher transfection of entrapped murine fibroblasts [18]. Yet, differences might also be attributed to the different cell ligand densities. Finally, another study showed that stiffer HA hydrogels ( $\sim 1200$ compared to $\sim 600 \mathrm{~Pa}$ ) led to higher transfection efficiency. Yet, a different amount of loaded nioplexes
$(0.12 \mu \mathrm{g} / \mu \mathrm{L}$ in the stiffer gels and $0.055 \mu \mathrm{g} / \mu \mathrm{L}$ in the softer ones) may also explain the difference observed [126].

In general, in spite of several studies assessing the biological effect of substrate stiffness [194, 195, 209-216], cytoskeletal trafficking/structural changes in cells encapsulated in biomaterials of different stiffness has been scarcely investigated, with no consensus having been reached as yet. Further research on this direction is limited by the fact that biomaterial stiffness influences several other different processes, including biomaterial degradation rate, cellular infiltration, migration and proliferation rate. Furthermore, whilst available research studies only compared the efficacy of two or three different fabrication systems, comprehensive studies of the interaction between different parameters are still needed. Thereby, potential mechanisms to increase DNA internalisation and nuclear trafficking by controlling biomaterial stiffness still remain to be determined.

\section{Mechanical loading}

In spite of discordances in terms of optimal loading regimens, it is recognised that mechanical compression modulates gene transfection, as it induces structural 
changes in the cytoskeleton. (Table 5) In A549 cells, equibiaxial stretching applied immediately after transfection and for as little as $30 \mathrm{~min}$, resulted in a 10-fold increase in gene transfer [223]. Similarly, A549 cells, subjected to equibiaxial stretching on silastic membranes, reorganised their cytoplasm, appeared more rounded than their unstretched counterparts and were more efficiently transfected via electroporation [222]. By using a dielectric elastomer actuator (DEA)-based stimulation bioreactors to generate tensile and contractile stress, in A549 cells, optimised cell compression (in terms of frequency and duty cycle) had a promoting effect, whereas different stretching regimens showed an inhibitory effect on transfection [38]. Although molecular mechanisms were not investigated, the decrease of gene transfection in stretched-as opposed to compressed-cells could be attributed to caveola flattening and disassembly, which was proven to be a consequence of excessive mechanical tension [224, 225]. This effect is probably mediated by the tyrosine kinase Src [225] and by the mDia1, a regulator of actin polymerisation [226, 227], which also acts as caveolar domain organisation [226]. Furthermore, excessive membrane tension might have prevented budding of clathrin-coated vesicles and slowed down their dynamics [207, 228].

Apart from inducing cytoskeletal remodelling, when performed during [218], or immediately after DNA administration [217], mechanical stimulation, by inducing pore formation to the cell membranes, facilitated DNA entering [217, 218, 229]. Nevertheless, such mechanisms were not largely investigated, nor has a consensus on the most efficient loading parameters been reached as yet. For instance, whilst uniaxial stretching decreased transfection of A549 cells [38], it did show a beneficial effect on murine primary lung epithelial cells [217] and HEK293 [220]. (Table 2) Furthermore, it is understood that optimal mechanical regimens increase cytoskeletal trafficking, but whether mechanical loading has any role in diverting endocytic pathways has not been investigated as yet, with only one suggesting a predominance of clathrin-coated vesicles, over caveolae and micropinocytosis for mechanically stimulated cells [38].

\section{Conclusions and future directions}

By combining biomaterials with gene therapy, it is possible to create tailored non-viral delivery systems, suitable for various applications. Different biomaterial fabrication strategies (i.e. DNA immobilisation, encapsulation or surface coating) lead to distinct temporal patterns of DNA release and transgene expression. The addition of mechanical or topographical cues, that facilitate cellular spreading, can further increase gene delivery. By incorporating ECM mimetics, synthetic peptides or through distinct chemical modifications, it is possible to target specific cell types or to create responsive systems with precise controlled features. Certain biomaterials may furthermore possess a therapeutic potential themselves, which can be combined with that of gene therapy [230]. Nevertheless, there still are many outstanding questions surrounding biomaterial-guided gene delivery. Firstly, endocytic pathways vary depending on cell type and DNA complex, and they still need to be fully characterised. Furthermore, nor potential mechanisms to escape the lysosomal network or mechanism of action of CPP are fully understood. It is not clear to which extent caveola-mediated endocytosis allows DNA to escape lysosomal trafficking, and eventually, the most effective strategies to divert DNA towards caveolar vesicles are to be unravelled. Caveolae closely co-align with actin stress fibres [34], and switch from clathrin to caveola-mediated endocytosis has been attributed to a change from actin polymerisation to depolymerisation [231], as Cav-1 appears to be dragged by depolymerising actin filaments and then concentrate with resulting actin patches [34, 226, 232]. Thereby, diversion of DNA trafficking towards caveolar vesicles could theoretically be facilitated by 3D embedding culture systems [91-93] and be further modulated by incorporating topographic cues [148] or ECM mimetics [187], which, by increasing cell adhesion area, force cells to rearrange actin filaments. Also, substrates with increased stiffness induced structural changes in the cytoskeleton, increased caveola dynamics [190], enhancing gene transfection [185, 188, 189]. Yet, development of robust engineered systems is challenging, as biomaterial mechanical properties influence a plethora of other different processes, including DNA diffusion and release, biomaterial degradation, cellular infiltration, migration and proliferation rate. All these processes may in turn affect transgene expression. This is even more evident when cells are embedded, as opposed to seeded, on the biomaterials. For embedding systems, not even a general consensus on whether increased stiffness facilitates [14] or stalls [101, 161] gene delivery has been reached as yet.

Mechanical loading also induces actin depolymerisation $[233,234]$ and structural changes in the microfilament and microtubule network [222]. The loadinginduced increase in gene delivery was effectively abolished by cytoskeletal-stabilising compounds [222]. Yet, despite having been proven, the beneficial effect of mechanical loading has not been extensively studied. It is not clear whether it was a different stimulus (e.g. uniaxial stretching versus compression [38]/equiaxial stretching) [219] or rather an excessive mechanical tension (independent on the type of loading) [207, 224, 225, 
Table 5 Mechanical stimulation and gene delivery. Research papers assessing the effect of different mechanical loading regimens on non-viral-mediated gene delivery

\begin{tabular}{lll}
\hline Type of mechanical stimulation & Cell type & Transfection system \\
\hline Uniaxial cyclic stretch $(0-10 \%, 0.5 \mathrm{~Hz}, 60$ & Murine primary & Cationic polymer TurboFect ${ }^{\mathrm{TM}}$ \\
min), equiaxial cyclic stretch $(5 \%, 05 . \mathrm{Hz}$, & lung epithelial & (ThermoFisher) or naked DNA added \\
$15 \mathrm{~min})$ and shear stress $(0.53$ degrees & cells on silicone & after loading \\
torsion, $0.5 \mathrm{~Hz}, 15 \mathrm{~min})$ & membranes &
\end{tabular}

Change in transfection efficiency Ref.

Independently on the type of stimulus, [217] optimal loading regimens increased transfection efficiency, compared to less intense or more intense regimens (in terms of \% time, loading time and frequency), for both polyplexes and naked DNA.

Using TurboFect ${ }^{\mathrm{TM}}, \%$ transfection was $\sim 63 \%$ for mechanically loaded samples and $\sim 5 \%$, for non-loaded control.

Sine Wave Generator, $100 \mathrm{~Hz}, 10 \mathrm{~V}$ amplitude for $4 \mathrm{~min}$

Uniaxial cyclic stretch, equiaxial cyclic stretch and shear stress bioreactors

Uniaxial stretching $(10 \%, 0.5 \mathrm{~Hz}, 30 \mathrm{~min})$

Stretching or compression (compressing ratio $2 \%, 4 \%, 6 \%$ and stretching ratio $4 \%$, $8 \%, 12 \%, 30,60$ and $100 \%$ duty cycle, 2 , 10, 100, $1000 \mathrm{mHz}$, for $10 \mathrm{~min}$ )
Myelogenous leukaemia cell line

K562 in

suspension

Dendritic cells and TurboFect ${ }^{\mathrm{TM}}$ or Lipofectamine ${ }^{\mathrm{TM}}$ added mesenchymal stem cells on

silicone membranes

HEK 293 on silicone membranes

A549 cells on silicone membranes

Naked siRNA added during loading after loading

Naked DNA added after loading Ned DNA added after loading

Lipofectamine $^{\mathrm{TM}}$, added after mechanical loading 10-time fold increase in transfection efficiency in mechanically loaded samples, compared to non-loaded control

In vivo rabbit

Ultrasound-induced mechanical stress (50 pulses of $250 \mu$ s in duration and 600 $\checkmark$ in amplitude), combined with high electric field (electroporation)

Equibiaxial cyclic stretch $(10 \%$ area stretch, $50 \%$ duty cycle, $0.5 \mathrm{~Hz}$, time variable from $30 \mathrm{~min}$ to $24 \mathrm{~h}$ )

Equibiaxial stretch, either continuous or cyclic (10\% area stretch, $10 \%$ duty cycle, $1 \mathrm{~Hz}$, either $30 \mathrm{~min}$ or $24 \mathrm{~h}$ ) retinas and

in vitro

chorioallantoic

membrane

A549 on

Pronectins $^{\mathrm{TM}}$ -

treated plates

A549 on laminincoated plates
Electroporation of naked DNA, performed before mechanical loading

Naked DNA added during stimulation

\section{0} indicating a higher expression of the subjected to ultrasound and electroporation treatments, compared to samples subjected to electroporation alone.

Twenty-four hours of cyclic stretch induced a onefold to sixfold increase in transfection, compared to nonloaded control

Naked DNA, or lipoplexes composed of Lipofectin ${ }^{\text {TM }}$ (Thermofisher) or electroporation. Transfection performed before and/or after loading

If performed before transfection, mechanical loading had no effect. If performed after transfection, cyclicbut not continuous - stretching significantly increased transfection efficiency for both Lipofectin ${ }^{T M}$ and electroporation but had no effect on naked DNA delivery system. Specifically, 30 min of stretching was sufficient to achieve a 2-fold (for Lipofectin $^{T M}$ ) or even a 10-fold (for electroporation) increase in transgene expression. 
228], which under certain conditions, led to caveola and clathrin vesicle disassembling.

Furthermore, the correlation between transgene expression and DNA endocytosis or nuclear entry is not always straightforward, with for instance collagen I coating showing a higher level of polyplex internalisation, but reduced intracellular trafficking and transgene expression, compared to fibronectin [160]. Similarly, compared to PLL, PEI polyplexes showed a lower cytoplasmic uptake, but a higher percentage of nuclear uptake [76]. Although this was beyond the scope of this review, it is noteworthy to mention that the in vivo fate of biomaterial-mediated gene delivery systems is also influenced by many other parameters, including eventual interaction with plasma proteins [235], or potential triggering of an innate immune response [236]. Only a better understanding of these processes may allow to the creation of novel robust engineered systems, potentially opening up a whole new area of biomaterial-guided gene delivery for non-viral systems.

\begin{abstract}
Abbreviations
ADSCs: Adipose-derived stem cells; BMSCs: Bone marrow mesenchymal stem cells; CPP: Cell-penetrating peptide; DEA: Dielectric elastomer actuator; DOPE: 1,2-Dioleoyl-sn-glycero-3-phosphoethanolamine (DOPE); DOTAP: 1,2Dioleoyl-3-trimethylammonium propane; DOTMA: 1,2-Di-O-octadecenyl-3trimethylammonium propane; DOPC: dioleoylphosphocholine; ECM: Extracellular matrix; ER: Endoplasmic reticulum; FAK: Focal adhesion kinases; GGT: Gamma-glutamyl transpeptidase; HA: Hyaluronic acid; hAMMSCs: Human amniotic membrane-derived mesenchymal stem cells; MAP: Microporous annealed particle; mDia1: Diaphanous-related formin-1; mESCs: Mouse embryonic stem cells; MMP: Matrix metalloproteinase; MSCs: Mesenchymal stem cells; MTOC: microtubule-organising centre; NPC: Nuclear pore complexes; OPF: Oligo (polyethylene glycol) fumarate; PAA: Poly(acrylic) acid; PAH: Poly(allylamine hydrochloride); PAMA M: Polyamidoamine; PBS: Poly(beta-amino ester); PD: Polydopamine; PDDA: Polydiallyldimethylammonium; PDMS: Polydimethylsiloxane; PEGDA: Poly(ethylene glycol) diacrylate; PEl: polyethylenimine; PLGA: Poly(lactic-co-glycolic acid); PLL: Polylysine; PMMA: Poly(methyl methacrylate); pnAC: Perinuclear actin cap; PTD: Protein transduction domain; RGD: Arginine-glycine-aspartate; siNWAs: Silicon nanowires; SMD: Surface-mediated gene delivery; $\gamma$-PGA: Poly- $\gamma$ glutamic acid
\end{abstract}

\section{Acknowledgements}

Not applicable.

\section{Author's contributions}

The author confirms sole responsibility for study conception, design, and manuscript preparation. The author read and approved the final manuscript.

\section{Funding}

This research was enabled in part by a funding contribution from Cystinosis Ireland (Charities Regulatory Authority No: 20053796). The funder had no role in the design of this study, in the collection, analysis, and interpretation of data and in writing the manuscript.

\section{Availability of data and materials}

Not applicable.

\section{Declarations}

Ethics approval and consent to participate Not applicable.
Consent for publication

Not applicable.

\section{Competing interests}

The author declares that she has no competing interests.

Received: 10 March 2021 Accepted: 9 June 2021

Published online: 17 June 2021

\section{References}

1. Graceffa V, Vinatier C, Guicheux J, Evans CH, Stoddart M, Alini M, Zeugolis DI (2018) State of art and limitations in genetic engineering to induce stable chondrogenic phenotype. Biotechnol Adv. 36(7):1855-1869. https://doi. org/10.1016/j.biotechadv.2018.07.004

2. Graceffa V, Vinatier C, Guicheux J, Stoddart M, Alini M, Zeugolis DI (2019) Chasing Chimeras - The elusive stable chondrogenic phenotype. Biomaterials 192:199-225. https://doi.org/10.1016/j.biomaterials.2018.11.014

3. Gonçalves GAR, de MA PR (2017) Gene therapy: advances, challenges and perspectives. Einstein (Sao Paulo) 15(3):369-375. https://doi.org/10.1590/s1 679-45082017rb4024

4. Shieh PB, Bönnemann CG, Müller-Felber W, Blaschek A, Dowling JJ, Kuntz NL, Seferian AM (2020) Re: "Moving forward after two deaths in a gene therapy trial of myotubular myopathy" by Wilson and Flotte. Hum Gene Ther 31(15-16):787. https://doi.org/10.1089/hum.2020.217

5. Evans CH, Ghivizzani SC, Robbins PD (2008) Arthritis gene therapy's first death. Arthritis Res Ther 10(3):110. https://doi.org/10.1186/ar2411

6. Sibbald B (2001) Death but one unintended consequence of gene-therapy trial. CMAJ 164:1612

7. Durymanov M, Reineke J (2018) Non-viral delivery of nucleic acids: insight into mechanisms of overcoming intracellular barriers. Front Pharmacol. 9: 971. https://doi.org/10.3389/fphar.2018.00971

8. Graceffa V (2021) Therapeutic potential of reactive oxygen species: state of the art and recent advances. SLAS Technol 26(2):140-158. https://doi.org/1 $0.1177 / 2472630320977450$

9. Graceffa V, Zeugolis DIDI (2019) Macromolecular crowding as a means to assess the effectiveness of chondrogenic media. J Tissue Eng Regen Med 13(2):217-231. https://doi.org/10.1002/term.2783

10. Treiser MD, Liu E, Dubin RA, Sung H-J, Kohn J, Moghe PV (2007) Profiling cell-biomaterial interactions via cell-based fluororeporter imaging. Biotechniques 43(3):361-368. https://doi.org/10.2144/000112533

11. Kang KB, Lawrence BD, Gao XR, Luo Y, Zhou Q, Liu A, Guaiquil VH, Rosenblatt MI (2017) Micro- and nanoscale topographies on silk regulate gene expression of human corneal epithelial cells. Invest Ophthalmol Vis Sci 58(14):6388-6398. https://doi.org/10.1167/iovs.17-22213

12. Tsygankova OM, Keen JH (2019) A unique role for clathrin light chain A in cell spreading and migration. J Cell Sci 132:jcs224030

13. Elkhatib N, Bresteau E, Baschieri F, Rioja AL, van Niel G, Vassilopoulos S, Montagnac G (2017) Tubular clathrin/AP-2 lattices pinch collagen fibers to support 3D cell migration. Science 356:eaal4713

14. Ledo AM, Vining KH, Alonso MJ, Garcia-Fuentes M, Mooney DJ (2020) Extracellular matrix mechanics regulate transfection and SOX9-directed differentiation of mesenchymal stem cells. Acta Biomater 110:153-163. https://doi.org/10.1016/j.actbio.2020.04.027

15. Lei P, Padmashali RM, Andreadis ST (2009) Cell-controlled and spatially arrayed gene delivery from fibrin hydrogels. Biomaterials 30(22):3790-3799. https://doi.org/10.1016/j.biomaterials.2009.03.049

16. Abbah SA, Thomas D, Browne S, O'Brien T, Pandit A, Zeugolis DI (2016) Cotransfection of decorin and interleukin-10 modulates pro-fibrotic extracellular matrix gene expression in human tenocyte culture. Sci Rep. 6(1). https://doi.org/10.1038/srep20922

17. Khalil AS, Yu X, Dang PN, Alsberg E, Murphy WL (2019) A microparticle approach for non-viral gene delivery within 3D human mesenchymal stromal cell aggregates. Acta Biomater 95:408-417. https://doi.org/10.1016/ j.actbio.2019.04.038

18. des Rieux A, Shikanov A, Shea LD (2009) Fibrin hydrogels for non-viral vector delivery in vitro. J Control Release 136:148-154, 2, doi: https://doi. org/10.1016/j.jconrel.2009.02.004

19. Hudecek M, Izsvák Z, Johnen S, Renner M, Thumann G, Ivics Z (2017) Going non-viral: the Sleeping Beauty transposon system breaks on through to the clinical side. Crit Rev Biochem Mol Biol 52(4):355-380. https://doi.org/10.1 080/10409238.2017.1304354 
20. Koirala A, Conley SM, Makkia R, Liu Z, Cooper MJ, Sparrow JR, Naash MI (2013) Persistence of non-viral vector mediated RPE65 expression: case for viability as a gene transfer therapy for RPE-based diseases. J Control Release 172(3):745-752. https://doi.org/10.1016/j.jconrel.2013.08.299

21. Ochiya T, Takahama $Y$, Nagahara S, Sumita $Y$, Hisada A, Itoh H, Nagai $Y$, Terada M (1999) New delivery system for plasmid DNA in vivo using atelocollagen as a carrier material: the Minipellet. Nat Med 5(6):707-710. https://doi.org/10.1038/9560

22. Jang J-H, Rives CB, Shea LD (2005) Plasmid delivery in vivo from porous tissue-engineering scaffolds: transgene expression and cellular transfection. Mol Ther 12(3):475-483. https://doi.org/10.1016/j.ymthe.2005.03.036

23. Salvay DM, Zelivyanskaya M, Shea LD (2010) Gene delivery by surface immobilization of plasmid to tissue-engineering scaffolds. Gene Ther 17(9): 1134-1141. https://doi.org/10.1038/gt.2010.79

24. Wolff JA, Ludtke JJ, Acsadi G, Williams P, Jani A (1992) Long-term persistence of plasmid DNA and foreign gene expression in mouse muscle. Hum Mol Genet 1(6):363-369. https://doi.org/10.1093/hmg/1.6.363

25. Koirala A, Makkia RS, Conley SM, Cooper MJ, Naash MI (2013) S/MARcontaining DNA nanoparticles promote persistent RPE gene expression and improvement in RPE65-associated LCA. Hum Mol Genet 22(8):1632-1642. https://doi.org/10.1093/hmg/ddt013

26. Kopatz I, Remy J-S, Behr J-P (2004) A model for non-viral gene delivery: through syndecan adhesion molecules and powered by actin. J Gene Med 6(7):769-776. https://doi.org/10.1002/jgm.558

27. Bengali Z, Rea JC, Gibly RF, Shea LD (2009) Efficacy of immobilized polyplexes and lipoplexes for substrate-mediated gene delivery. Biotechnol Bioeng 102(6):1679-1691. https://doi.org/10.1002/bit.22212

28. Hattori $Y$ (2017) Progress in the development of lipoplex and polyplex modified with anionic polymer for efficient gene delivery. J Genet Med Gene Ther 1(1):3-18. https://doi.org/10.29328/journal.jgmgt.1001002

29. Grijalvo S, Puras G, Zárate J, Sainz-Ramos M, Qtaish NAL, López T, Mashal M, Attia N, Díaz D, Pons R, Fernández E, Pedraz JL, Eritja R (2019) Cationic niosomes as non-viral vehicles for nucleic acids: challenges and opportunities in gene delivery. Pharmaceutics 11(2):50. https://doi.org/10.33 90/pharmaceutics11020050

30. Ag Seleci D, Seleci M, Walter J-G, Stahl F, Scheper T (2016) Niosomes as nanoparticular drug carriers: fundamentals and recent applications. J Nanomater 2016:7372306

31. Gonzalez-Fernandez T, Sathy BN, Hobbs C, Cunniffe GM, McCarthy HO, Dunne NJ, Nicolosi V, O'Brien FJ, Kelly DJ (2017) Mesenchymal stem cell fate following non-viral gene transfection strongly depends on the choice of delivery vector. Acta Biomater 55:226-238. https://doi.org/10.1016/j.actbio.2 017.03 .044

32. Kumari S, MGS, Mayor S (2010) Endocytosis unplugged: multiple ways to enter the cell. Cell Res 20(3):256-275. https://doi.org/10.1038/cr.2010.19

33. Ni R, Feng R, Chau Y (2019) Synthetic approaches for nucleic acid delivery: choosing the right carriers. Life (Basel) 9:59. https://doi.org/10.3390/life903 0059

34. Echarri A, Del Pozo MA (2015) Caveolae - mechanosensitive membrane invaginations linked to actin filaments. J Cell Sci 128:2747 LP-2742758

35. Li L, Wan T, Wan M, Liu B, Cheng R, Zhang R (2015) The effect of the size of fluorescent dextran on its endocytic pathway. Cell Biol Int 39(5):531-539. https://doi.org/10.1002/cbin.10424

36. Tejeda-Muñoz N, Albrecht LV, Bui MH, De Robertis EM (2019) Wnt canonical pathway activates macropinocytosis and lysosomal degradation of extracellular proteins. Proc Natl Acad Sci 116:10402 LP-10410411

37. von Gersdorff K, Sanders NN, Vandenbroucke R, De Smedt SC, Wagner E, Ogris M (2006) The internalization route resulting in successful gene expression depends on both cell line and polyethylenimine polyplex type. Mol Ther 14(5):745-753. https://doi.org/10.1016/j. ymthe.2006.07.006

38. Gao C, Li Z, Zou J, Cheng J, Jiang K, Liu C, Gu G, Tao W, Song J (2020) Mechanical effect on gene transfection based on dielectric elastomer actuator. ACS Appl Bio Mater 3(5):2617-2625. https://doi.org/10.1021/acsa bm.9b01199

39. Zuhorn IS, Kalicharan R, Hoekstra D (2002) Lipoplex-mediated transfection of mammalian cells occurs through the cholesterol-dependent clathrinmediated pathway of endocytosis. J Biol Chem 277(20):18021-18028. https://doi.org/10.1074/jbc.M111257200

40. Cardarelli F, Pozzi D, Bifone A, Marchini C, Caracciolo G (2012) Cholesteroldependent macropinocytosis and endosomal escape control the transfection efficiency of lipoplexes in CHO living cells. Mol Pharm 9(2):334340. https://doi.org/10.1021/mp200374e

41. Lazebnik M, Keswani RK, Pack DW (2016) Endocytic transport of polyplex and lipoplex siRNA vectors in HeLa cells. Pharm Res 33(12):2999-3011. https://doi.org/10.1007/s11095-016-2022-1

42. Pozzi D, Marchini C, Cardarelli F, Amenitsch H, Garulli C, Bifone A, Caracciolo G (2012) Transfection efficiency boost of cholesterol-containing lipoplexes. Biochim Biophys Acta 1818(9):2335-2343. https://doi.org/10.1016/j.bba mem.2012.05.017

43. Vercauteren D, Vandenbroucke RE, Jones AT, Rejman J, Demeester J, De Smedt SC, Sanders NN, Braeckmans K (2010) The use of inhibitors to study endocytic pathways of gene carriers: optimization and pitfalls. Mol Ther 18(3):561-569. https://doi.org/10.1038/mt.2009.281

44. Rejman J, Bragonzi A, Conese M (2005) Role of clathrin- and caveolaemediated endocytosis in gene transfer mediated by lipo- and polyplexes. Mol Ther 12(3):468-474. https://doi.org/10.1016/j.ymthe.2005.03.038

45. Zhang X-X, Allen PG, Grinstaff M (2011) Macropinocytosis is the major pathway responsible for DNA transfection in $\mathrm{CHO}$ cells by a charge-reversal amphiphile. Mol Pharm 8(3):758-766. https://doi.org/10.1021/mp100366h

46. Rejman J, Oberle V, Zuhorn IS, Hoekstra D (2004) Size-dependent internalization of particles via the pathways of clathrin- and caveolaemediated endocytosis. Biochem J 377(1):159-169. https://doi.org/10.1042/ bj20031253

47. Grosse S, Aron Y, Thévenot G, Monsigny M, Fajac I (2007) Cytoskeletal involvement in the cellular trafficking of plasmid/PEl derivative complexes. J Control Release 122(1):111-117. https://doi.org/10.1016/j.jconrel.2007.06.015

48. Coppola S, Cardarelli F, Pozzi D, Estrada LC, Digman MA, Gratton E, Bifone A, Marianecci C, Caracciolo G (2013) The role of cytoskeleton networks on lipid-mediated delivery of DNA. Ther Deliv 4(2):191-202. https://doi.org/1 $0.4155 /$ tde. 12.151

49. Phuyal S, Farhan H (2019) Multifaceted Rho GTPase signaling at the endomembranes. Front. Cell Dev. Biol. 7:127. https://doi.org/10.3389/fcell.2 019.00127

50. Hervé JC, Bourmeyster N (2015) Rho GTPases at the crossroad of signaling networks in mammals. Small GTPases 6(2):43-48. https://doi.org/10.1080/21 541248.2015.1044811

51. Vaughan EE, Dean DA (2006) Intracellular trafficking of plasmids during transfection is mediated by microtubules. Mol Ther 13(2):422-428. https:// doi.org/10.1016/j.ymthe.2005.10.004

52. Rosazza C, Escoffre J-M, Zumbusch A, Rols M-P (2011) The actin cytoskeleton has an active role in the electrotransfer of plasmid DNA in mammalian cells. Mol Ther 19(5):913-921. https://doi.org/10.1038/mt.2010.3 03

53. Rosazza C, Deschout H, Buntz A, Braeckmans K, Rols M-P, Zumbusch A (2016) Endocytosis and endosomal trafficking of DNA after gene electrotransfer in vitro. Mol Ther Nucleic Acids 5:e286-e286. https://doi. org/10.1038/mtna.2015.59

54. Kutsuzawa K, Tada S, Hossain S, Fukuda K, Maruyama K, Akiyama Y, Akaike T, Chowdhury EH (2009) Disrupting actin filaments promotes efficient transfection of a leukemia cell line using cell adhesive protein-embedded carbonate apatite particles. Anal Biochem 388(1):164-166. https://doi.org/1 0.1016/j.ab.2009.02.006

55. Alshehri A, Grabowska A, Stolnik S (2018) Pathways of cellular internalisation of liposomes delivered siRNA and effects on siRNA engagement with target mRNA and silencing in cancer cells. Sci Rep 8(1):3748. https://doi.org/10.103 8/s41598-018-22166-3

56. Cardarelli F, Digiacomo L, Marchini C, Amici A, Salomone F, Fiume G, Rossetta A, Gratton E, Pozzi D, Caracciolo G (2016) The intracellular trafficking mechanism of Lipofectamine-based transfection reagents and its implication for gene delivery. Sci Rep 6(1):25879. https://doi.org/10.1038/ srep25879

57. Qin B, Yuan X, Jiang M, Yin H, Luo Z, Zhang J, Zhu C, Li X, Shi Y, Luo L, Du $Y$, You J (2020) Targeting DNA to the endoplasmic reticulum efficiently enhances gene delivery and therapy. Nanoscale 12(35):18249-18262. https://doi.org/10.1039/D0NR03156A

58. Ramos-Murillo Al, Rodríguez E, Beltrán K, Ricaurte C, Camacho B, Salquero G, Godoy-Silva RD (2020) Efficient non-viral gene modification of mesenchymal stromal cells from umbilical cord Wharton's jelly with polyethylenimine. Pharmaceutics 12(9). https://doi.org/10.3390/pharmaceutics12090896

59. Martens TF, Remaut K, Demeester J, De Smedt SC, Braeckmans K (2014) Intracellular delivery of nanomaterials: How to catch endosomal escape 
in the act. Nano Today 9(3):344-364. https://doi.org/10.1016/j.nantod.2 014.04.011

60. Vermeulen LMP, De Smedt SC, Remaut K, Braeckmans K (2018) The proton sponge hypothesis: Fable or fact? Eur J Pharm Biopharm 129:184-190. https://doi.org/10.1016/j.ejpb.2018.05.034

61. Huang G, Chen Q, Wu W, Wang J, Chu PK, Bai H, Tang G (2020) Reconstructed chitosan with alkylamine for enhanced gene delivery by promoting endosomal escape. Carbohydr Polym 227:115339. https://doi. org/10.1016/j.carbpol.2019.115339

62. Kanthamneni N, Yung B, Lee RJ (2016) Effect of Eudragit on in vitro transfection efficiency of PEI-DNA complexes. Anticancer Res 36:81 LP-81 85

63. Lacraz G, Figeac F, Movassat J, Kassis N, Coulaud J, Galinier A, Leloup C, Bailbé D, Homo-Delarche F, Portha B (2009) Diabetic beta-cells can achieve self-protection against oxidative stress through an adaptive up-regulation of their antioxidant defenses. Plos One 4(8):e6500. https://doi.org/10.1371/ journal.pone.0006500

64. Guillem V, Aliño S (2004) Transfection pathways of nonspecific and targeted PEl-polyplexes Review Article. Gene Ther Mol Biol 8:369-384

65. Nel AE, Mädler L, Velegol D, Xia T, Hoek EMV, Somasundaran P, Klaessig F, Castranova V, Thompson M (2009) Understanding biophysicochemical interactions at the nano-bio interface. Nat Mater 8(7):543-557. https://doi. org/10.1038/nmat2442

66. Benjaminsen RV, Mattebjerg MA, Henriksen JR, Moghimi SM, Andresen TL (2013) The possible "proton sponge " effect of polyethylenimine (PEI) does not include change in lysosomal pH. Mol Ther 21(1):149-157. https://doi. org/10.1038/mt.2012.185

67. Godbey WT, Barry MA, Saggau P, Wu KK, Mikos AG (2000) Poly(ethylenimine)-mediated transfection: A new paradigm for gene delivery. J Biomed Mater Res 51(3):321-328. https://doi.org/10.1002/1097-4 636(20000905)51:3<321::AID-JBM5>3.0.CO;2-R

68. Funhoff AM, van Nostrum CF, Koning GA, Schuurmans-Nieuwenbroek NME, Crommelin DJA, Hennink WE (2004) Endosomal escape of polymeric gene delivery complexes is not always enhanced by polymers buffering at low pH. Biomacromolecules 5(1):32-39. https://doi.org/10.1021/bm034041+

69. Forrest ML, Meister GE, Koerber JT, Pack DW (2004) Partial acetylation of polyethylenimine enhances in vitro gene delivery. Pharm Res 21(2):365-371. https://doi.org/10.1023/B:PHAM.0000016251.42392.1e

70. Sahni A, Qian Z, Pei D (2020) Cell-penetrating peptides escape the endosome by inducing vesicle budding and collapse. ACS Chem Biol 15(9): 2485-2492. https://doi.org/10.1021/acschembio.0c00478

71. van der Aa MAEM, Mastrobattista E, Oosting RS, Hennink WE, Koning GA, Crommelin DJA (2006) The nuclear pore complex: the gateway to successful nonviral gene delivery. Pharm Res 23(3):447-459. https://doi.org/1 0.1007/s11095-005-9445-4

72. Brunner S, Sauer T, Carotta S, Cotten M, Saltik M, Wagner E (2000) Cell cycle dependence of gene transfer by lipoplex, polyplex and recombinant adenovirus. Gene Ther 7(5):401-407. https://doi.org/10.1038/sj.gt.3301102

73. Symens N, Soenen SJ, Rejman J, Braeckmans K, De Smedt SC, Remaut K (2012) Intracellular partitioning of cell organelles and extraneous nanoparticles during mitosis. Adv Drug Deliv Rev 64(1):78-94. https://doi. org/10.1016/j.addr.2011.11.012

74. Remaut K, Symens N, Lucas B, Demeester J, De Smedt SC (2014) Cell division responsive peptides for optimized plasmid DNA delivery: The mitotic window of opportunity? I Control Release 179:1-9. https://doi.org/1 0.1016/j.jconrel.2014.01.013

75. Pollard H, Remy JS, Loussouarn G, Demolombe S, Behr JP, Escande D (1998) Polyethylenimine but not cationic lipids promotes transgene delivery to the nucleus in mammalian cells. J Biol Chem 273(13):7507-7511. https://doi. org/10.1074/jbc.273.13.7507

76. Farrell L-L, Pepin J, Kucharski C, Lin X, Xu Z, Uludag H (2007) A comparison of the effectiveness of cationic polymers poly-L-lysine (PLL) and polyethylenimine (PEI) for non-viral delivery of plasmid DNA to bone marrow stromal cells (BMSC). Eur J Pharm Biopharm Off J Arbeitsgemeinschaft fur Pharm Verfahrenstechnik eV 65(3):388-397. https:// doi.org/10.1016/j.ejpb.2006.11.026

77. Symens N, Walczak R, Demeester J, Mattaj I, De Smedt SC, Remaut K (2011) Nuclear inclusion of nontargeted and chromatin-targeted polystyrene beads and plasmid DNA containing nanoparticles. Mol Pharm 8(5):1757-1766. https://doi.org/10.1021/mp200120v

78. Remaut K, Sanders NN, Fayazpour F, Demeester J, De Smedt SC (2006) Influence of plasmid DNA topology on the transfection properties of
DOTAP/DOPE lipoplexes. J Control Release 115(3):335-343. https://doi.org/1 0.1016/j.jconrel.2006.08.009

79. Wang Y, You C, Wei R, Zu J, Song C, Li J, Yan J (2017) Modification of human umbilical cord blood stem cells using polyethylenimine combined with modified TAT peptide to enhance BMP-2 production. Biomed Res Int 2017:2971413

80. Yamano S, Dai J, Hanatani S, Haku K, Yamanaka T, Ishioka M, Takayama T, Yuvienco C, Khapli S, Moursi AM, Montclare JK (2014) Long-term efficient gene delivery using polyethylenimine with modified Tat peptide. Biomaterials 35(5): 1705-1715. https://doi.org/10.1016/j.biomaterials.2013.11.012

81. Bathori G, Cervenak L, Karadi I (2004) Caveolae--an alternative endocytotic pathway for targeted drug delivery. Crit Rev Ther Drug Carrier Syst 21(2):6795. https://doi.org/10.1615/critrevtherdrugcarriersyst.v21.i2.10

82. Le PU, Nabi IR (2003) Distinct caveolae-mediated endocytic pathways target the Golgi apparatus and the endoplasmic reticulum. J Cell Sci 116:1059 LP1051071

83. Reilly MJ, Larsen JD, Sullivan MO (2012) Polyplexes traffic through caveolae to the Golgi and endoplasmic reticulum en route to the nucleus. Mol Pharm 9(5):1280-1290. https://doi.org/10.1021/mp200583d

84. Hwang J, Sullivan MO, Kiick KL (2020) Targeted drug delivery via the use of ECM-mimetic materials. Front. Bioeng. Biotechnol. 8:69. https://doi.org/10.33 89/fbioe.2020.00069

85. Manzanares D, Ceña V (2020) Endocytosis: the nanoparticle and submicron nanocompounds gateway into the cell. Pharmaceutics 12(4). https://doi. org/10.3390/pharmaceutics12040371

86. Marmiroli M, Maestri E, Pagano L, Robinson BH, Ruotolo R, Marmiroli N (2019) Chapter 8 - Toxicology assessment of engineered nanomaterials: innovation and tradition. In: Marmiroli N, White JC, Song JBT-E to EN in the E (eds) Micro and Nano Technologies. Elsevier, pp 209-234

87. Ruseska I, Zimmer A (2020) Internalization mechanisms of cell-penetrating peptides. Beilstein J Nanotechnol 11:101-123. https://doi.org/10.3762/bjna no.11.10

88. Parodi A, Corbo C, Cevenini A, Molinaro R, Palomba R, Pandolfi L, Agostini M, Salvatore F, Tasciotti E (2015) Enabling cytoplasmic delivery and organelle targeting by surface modification of nanocarriers. Nanomedicine (Lond) 10(12):1923-1940. https://doi.org/10.2217/nnm.15.39

89. Yuan $X$, Qin B, Yin H, Shi Y, Jiang M, Luo L, Luo Z, Zhang J, Li X, Zhu C, Du Y, You J (2020) Virus-like nonvirus cationic liposome for efficient gene delivery via endoplasmic reticulum pathway. ACS Cent Sci 6(2):174-188. https://doi.org/10.1021/acscentsci.9b01052

90. Pavelka M, Roth J (2010) Nuclear envelope and rough endoplasmic reticulum. In: Springer (ed) Functional Ultrastructure. Vienna, pp 30-31

91. Truong NF, Lesher-Pérez SC, Kurt E, Segura T (2019) Pathways governing polyethylenimine polyplex transfection in microporous annealed particle scaffolds. Bioconjug Chem 30(2):476-486. https://doi.org/10.1021/acs. bioconjchem.8b00696

92. Urello MA, Kiick KL, Sullivan MO (2017) ECM turnover-stimulated gene delivery through collagen-mimetic peptide-plasmid integration in collagen. Acta Biomater 62:167-178. https://doi.org/10.1016/j.actbio.2 017.08 .038

93. Hsu S, Ho T-T, Tseng T-C (2012) Nanoparticle uptake and gene transfer efficiency for MSCs on chitosan and chitosan-hyaluronan substrates. Biomaterials 33(14):36393650. https:/doi.org/10.1016/.jbiomaterials.2012.02.005

94. Nimse SB, Song K, Sonawane MD, Sayyed DR, Kim T (2014) Immobilization techniques for microarray: challenges and applications. Sensors (Basel) 14(12):22208-22229. https://doi.org/10.3390/s141222208

95. Jang J-H, Bengali Z, Houchin TL, Shea LD (2006) Surface adsorption of DNA to tissue engineering scaffolds for efficient gene delivery. J Biomed Mater Res A 77(1):50-58. https://doi.org/10.1002/jbm.a.30643

96. Singh V, Zharnikov M, Gulino A, Gupta T (2011) DNA immobilization, delivery and cleavage on solid supports. J Mater Chem 21(29):10602-10618. https://doi.org/10.1039/c0jm04359a

97. Jang J-H, Schaffer DV, Shea LD (2011) Engineering biomaterial systems to enhance viral vector gene delivery. Mol Ther 19(8):1407-1415. https://doi. org/10.1038/mt.2011.111

98. Gower RM, Shea LD (2013) Biomaterial scaffolds for controlled, localized gene delivery of regenerative factors. Adv wound care 2(3):100-106. https:// doi.org/10.1089/wound.2011.0325

99. Tokatlian T, Cam C, Segura T (2015) Porous hyaluronic acid hydrogels for localized nonviral DNA delivery in a diabetic wound healing model. Adv Healthc Mater 4(7):1084-1091. https://doi.org/10.1002/adhm.201400783 
100. Shepard JA, Virani FR, Goodman AG, Gossett TD, Shin S, Shea LD (2012) Hydrogel macroporosity and the prolongation of transgene expression and the enhancement of angiogenesis. Biomaterials 33(30):7412-7421. https:// doi.org/10.1016/j.biomaterials.2012.06.081

101. Tokatlian T, Cam C, Segura T (2014) Non-viral DNA delivery from porous hyaluronic acid hydrogels in mice. Biomaterials 35(2):825-835. https://doi. org/10.1016/j.biomaterials.2013.10.014

102. Ehsanipour A, Nguyen T, Aboufadel T, Sathialingam M, Cox P, Xiao W, Walthers CM, Seidlits SK (2019) Injectable, hyaluronic acid-based scaffolds with macroporous architecture for gene delivery. Cell Mol Bioeng 12(5):399413. https://doi.org/10.1007/s12195-019-00593-0

103. Dadsetan M, Szatkowski JP, Shogren KL, Yaszemski MJ, Maran A (2009) Hydrogel-mediated DNA delivery confers estrogenic response in nonresponsive osteoblast cells. J Biomed Mater Res A 91(4):1170-1177. https://doi.org/10.1002/jbm.a.32291

104. Chalanqui MJ, Pentlavalli S, McCrudden C, Chambers P, Ziminska M, Dunne N, McCarthy HO (2019) Influence of alginate backbone on efficacy of thermo-responsive alginate-g-P(NIPAAm) hydrogel as a vehicle for sustained and controlled gene delivery. Mater Sci Eng C 95:409-421. https://doi.org/1 0.1016/j.msec.2017.09.003

105. Pannier AK, Segura T (2013) Surface- and hydrogel-mediated delivery of nucleic acid nanoparticles. Methods Mol Biol 948:149-169. https://doi.org/1 0.1007/978-1-62703-140-0 11

106. Siegman S, Truong NF, Segura T (2015) Encapsulation of PEGylated lowmolecular-weight PEl polyplexes in hyaluronic acid hydrogels reduces aggregation. Acta Biomater 28:45-54. https://doi.org/10.1016/j.actbio.2015. 09.020

107. Lei Y, Rahim M, Ng Q, Segura T (2011) Hyaluronic acid and fibrin hydrogels with concentrated DNA/PEI polyplexes for local gene delivery. J Control Release 153(3):255-261. https://doi.org/10.1016/j. jconrel.2011.01.028

108. Jo A, Ringel-Scaia VM, McDaniel DK, Thomas CA, Zhang R, Riffle JS, Allen IC, Davis RM (2020) Fabrication and characterization of PLGA nanoparticles encapsulating large CRISPR-Cas9 plasmid. J Nanobiotechnol 18(1):16. https://doi.org/10.1186/s12951-019-0564-1

109. Carthew J, Donderwinkel I, Shrestha S, Truong VX, Forsythe JS, Frith JE (2020) In situ miRNA delivery from a hydrogel promotes osteogenesis of encapsulated mesenchymal stromal cells. Acta Biomater 101:249-261. https://doi.org/10.1016/j.actbio.2019.11.016

110. Dave N, Chan MY, Huang P-JJ, Smith BD, Liu J (2010) Regenerable DNAfunctionalized hydrogels for ultrasensitive, instrument-free mercury(II) detection and removal in water. J Am Chem Soc 132(36):12668-12673. https://doi.org/10.1021/ja106098j

111. Fukunaka Y, Iwanaga K, Morimoto K, Kakemi M, Tabata Y (2002) Controlled release of plasmid DNA from cationized gelatin hydrogels based on hydrogel degradation. J Control Release 80(1-3):333-343. https://doi.org/1 0.1016/S0168-3659(02)00026-3

112. Balashanmugam MV, Nagarethinam S, Jagani H, Josyula VR, Alrohaimi A, Udupa N (2014) Preparation and characterization of novel PBAE/PLGA polymer blend microparticles for DNA vaccine delivery. Sci World J 2014: 385135

113. Wang Z, Shen H, Song S, Zhang L, Chen W, Dai J, Zhang Z (2018) Graphene oxide incorporated PLGA nanofibrous scaffold for solid phase gene delivery into mesenchymal stem cells. J Nanosci Nanotechnol 18(4):2286-2293. https://doi.org/10.1166/jnn.2018.14362

114. Zandieh M, Hagar BM, Liu J (2020) Interfacing DNA and polydopamine nanoparticles and its applications. Part Part Syst Charact 37(11):2000208. https://doi.org/10.1002/ppsc.202000208

115. Urello MA, Kiick KL, Sullivan MO (2016) Integration of growth factor gene delivery with collagen-triggered wound repair cascades using collagenmimetic peptides. Bioeng Transl Med 1(2):207-219. https://doi.org/10.1002/ btm2.10037

116. Bai L, Zhao J, Wang M, Feng Y, Ding J (2020) Matrix-metalloproteinaseresponsive gene delivery surface for enhanced in situ endothelialization. ACS Appl Mater Interfaces 12(36):40121-40132. https://doi.org/10.1021/acsa mi.0c11971

117. Zhang H, Huang J-J, Wang J, Hu M, Chen X-C, Sun W, Ren K-F, Ji J (2019) Surface-mediated stimuli-responsive gene delivery based on breath figure film combined with matrix metalloproteinase-sensitive hydrogel. ACS Biomater Sci Eng 5(12):6610-6616. https://doi.org/10.1021/acsbiomaterials. 9b01353
118. Lei $Y$, Segura T (2009) DNA delivery from matrix metalloproteinase degradable poly(ethylene glycol) hydrogels to mouse cloned mesenchymal stem cells. Biomaterials 30(2):254-265. https://doi.org/10.1016/j.biomateria Is.2008.09.027

119. Liu Y, Zhao N, Xu F-J (2019) pH-responsive degradable dextran-quantum dot nanohybrids for enhanced gene delivery. ACS Appl Mater Interfaces 11(38):34707-34716. https://doi.org/10.1021/acsami.9b12198

120. Hu C-H, Zhang X-Z, Zhang L, Xu X-D, Zhuo R-X (2009) Temperature- and $\mathrm{pH}$-sensitive hydrogels to immobilize heparin-modified PEI/DNA complexes for sustained gene delivery. J Mater Chem 19(47):8982-8989. https://doi. org/10.1039/b916310g

121. Madry H, Gao L, Rey-Rico A, Venkatesan JK, Müller-Brandt K, Cai X, Goebel L, Schmitt G, Speicher-Mentges S, Zurakowski D, Menger MD, Laschke MW Cucchiarini M (2020) Thermosensitive hydrogel based on PEO-PPO-PEO poloxamers for a controlled in situ release of recombinant adeno-associated viral vectors for effective gene therapy of cartilage defects. Adv Mater 32: e1906508

122. Ryu J-Y, Won E-J, Lee HAR, Kim JH, Hui E, Kim HP, Yoon T-J (2020) Ultrasound-activated particles as CRISPR/Cas9 delivery system for androgenic alopecia therapy. Biomaterials 232:119736. https://doi.org/10.101 6/j.biomaterials.2019.119736

123. Liufu C, Li Y, Tu J, Zhang H, Yu J, Wang Y, Huang P, Chen Z (2019) Echogenic PEGylated PEI-loaded microbubble As efficient gene delivery system. Int J Nanomedicine 14:8923-8941. https://doi.org/10.2147/IJN.S217338

124. Yao L, Weng W, Cheng K, Wang L, Dong L, Lin J, Sheng K (2020) Novel platform for surface-mediated gene delivery assisted with visible-light illumination. ACS Appl Mater Interfaces 12(15):17290-17301. https://doi. org/10.1021/acsami.0c00511

125. Zhang H, Wang J, Hu M, Li B-C, Li H, Chen T-T, Ren K-F, Ji J, Jing Q-M, Fu GS (2019) Photothermal-assisted surface-mediated gene delivery for enhancing transfection efficiency. Biomater Sci 7(12):5177-5186. https://doi. org/10.1039/C9BM01284B

126. Villate-Beitia I, Truong NF, Gallego I, Zárate J, Puras G, Pedraz JL, Segura T (2018) Hyaluronic acid hydrogel scaffolds loaded with cationic niosomes for efficient non-viral gene delivery. RSC Adv 8(56):31934-31942. https://doi. org/10.1039/C8RA05125A

127. Saul JM, Linnes MP, Ratner BD, Giachelli CM, Pun SH (2007) Delivery of nonviral gene carriers from sphere-templated fibrin scaffolds for sustained transgene expression. Biomaterials 28(31):4705-4716. https://doi.org/10.101 6/j.biomaterials.2007.07.026

128. Zhang J, Sen A, Cho E, Lee JS, Webb K (2017) Poloxamine/fibrin hybrid hydrogels for non-viral gene delivery. J Tissue Eng Regen Med 11(1):246255. https://doi.org/10.1002/term.1906

129. Delgado LM, Bayon Y, Pandit A, Zeugolis DI (2015) To cross-link or not to cross-link? Cross-linking associated foreign body response of collagen-based devices. Tissue Eng Part B Rev 21(3):298-313. https://doi.org/10.1089/ten. teb.2014.0290

130. Keeney M, Chung MT, Zielins ER, Paik KJ, McArdle A, Morrison SD, Ransom RC, Barbhaiya N, Atashroo D, Jacobson G, Zare RN, Longaker MT, Wan DC, Yang F (2016) Scaffold-mediated BMP-2 minicircle DNA delivery accelerated bone repair in a mouse critical-size calvarial defect model. J Biomed Mater Res A 104(8):2099-2107. https://doi.org/10.1002/ jbm.a.35735

131. Wieland JA, Houchin-Ray TL, Shea LD (2007) Non-viral vector delivery from PEG-hyaluronic acid hydrogels. J Control Release 120(3):233-241. https://doi. org/10.1016/j.jconrel.2007.04.015

132. Lei $Y$, Huang S, Sharif-Kashani $P$, Chen $Y$, Kavehpour P, Segura T (2010) Incorporation of active DNA/cationic polymer polyplexes into hydrogel scaffolds. Biomaterials 31(34):9106-9116. https://doi.org/10.1016/j.biomateria Is.2010.08.016

133. Avilés MO, Lin C-H, Zelivyanskaya M, Graham JG, Boehler RM, Messersmith PB, Shea LD (2010) The contribution of plasmid design and release to in vivo gene expression following delivery from cationic polymer modified scaffolds. Biomaterials 31(6):1140-1147. https://doi.org/10.1016/j.biomateria Is.2009.10.035

134. Mantz A, Pannier AK (2019) Biomaterial substrate modifications that influence cell-material interactions to prime cellular responses to nonviral gene delivery. Exp Biol Med (Maywood) 244(2):100-113. https://doi.org/1 $0.1177 / 1535370218821060$

135. Bengali Z, Shea LD (2005) Gene delivery by immobilization to cell-adhesive substrates. MRS Bull 30(9):659-662. https://doi.org/10.1557/mrs2005.193 
136. Hu W-W, Ting J-C (2019) Gene immobilization on alginate/polycaprolactone fibers through electrophoretic deposition to promote in situ transfection efficiency and biocompatibility. Int J Biol Macromol 121:1337-1345. https:// doi.org/10.1016/j.jijbiomac.2018.09.043

137. Hong CA, Son HY, Nam YS (2018) Layer-by-layer siRNA/poly(L-lysine) multilayers on polydopamine-coated surface for efficient cell adhesion and gene silencing. Sci Rep 8(1):7738. https://doi.org/10.1038/s41598-01 8-25655-7

138. Kim S-H, Yu SJ, Kim I, Choi J, Choi YH, Im SG, Hwang NS (2019) A biofunctionalized viral delivery patch for spatially defined transfection. Chem Commun (Camb) 55(16):2317-2320. https://doi.org/10.1039/ C8CC09768B

139. Wang K, Bruce A, Mezan R, Kadiyala A, Wang L, Dawson J, Rojanasakul Y, Yang Y (2016) Nanotopographical modulation of cell function through nuclear deformation. ACS Appl Mater Interfaces 8(8):5082-5092. https://doi. org/10.1021/acsami.5b10531

140. Hamann A, Thomas AK, Kozisek T, Farris E, Lück S, Zhang Y, Pannier AK (2020) Screening a chemically defined extracellular matrix mimetic substrate library to identify substrates that enhance substrate-mediated transfection. Exp Biol Med (Maywood) 245(7):606-619. https://doi.org/10.1177/153537022 0913501

141. Papenburg BJ, Rodrigues ED, Wessling M, Stamatialis D (2010) Insights into the role of material surface topography and wettability on cellmaterial interactions. Soft Matter 6(18):4377-4388. https://doi.org/10.103 9/b927207k

142. Yim EKF, Darling EM, Kulangara K, Guilak F, Leong KW (2010) Nanotopographyinduced changes in focal adhesions, cytoskeletal organization, and mechanical properties of human mesenchymal stem cells. Biomaterials 31(6):1299-1306. https://doi.org/10.1016/j.biomaterials.2009.10.037

143. Wang P-Y, Ding S, Sumer H, Wong RC-B, Kingshott P (2017) Heterogeneity of mesenchymal and pluripotent stem cell populations grown on nanogrooves and nanopillars. J Mater Chem B 5(39):7927-7938. https://doi. org/10.1039/C7TB01878A

144. Metavarayuth K, Sitasuwan P, Zhao X, Lin Y, Wang Q (2016) Influence of surface topographical cues on the differentiation of mesenchymal stem cells in vitro. ACS Biomater Sci Eng 2(2):142-151. https://doi.org/10.1021/a csbiomaterials.5b00377

145. Kang M, Leal C (2016) Soft nanostructured films for actuated surface-based siRNA delivery. Adv Funct Mater 26(31):5610-5620. https://doi.org/10.1002/a dfm. 201600681

146. Yang Y, Wang X, Hu X, Kawazoe N, Yang Y, Chen G (2019) Influence of cell morphology on mesenchymal stem cell transfection. ACS Appl Mater Interfaces 11(2):1932-1941. https://doi.org/10.1021/acsami.8b20490

147. Wang P-Y, Lian Y-S, Chang R, Liao W-H, Chen W-S, Tsai W-B (2017) Modulation of PEl-mediated gene transfection through controlling cytoskeleton organization and nuclear morphology via nanogrooved topographies. ACS Biomater Sci Eng 3(12):3283-3291. https://doi.org/10.1 021/acsbiomaterials.7b00617

148. Teo BKK, Goh S-H, Kustandi TS, Loh WW, Low HY, Yim EKF (2011) The effect of micro and nanotopography on endocytosis in drug and gene delivery systems. Biomaterials 32(36):9866-9875. https://doi.org/10.1016/j.biomateria Is.2011.08.088

149. Chen Y, Aslanoglou S, Gervinskas G, Abdelmaksoud H, Voelcker NH, Elnathan R (2019) Cellular deformations induced by conical silicon nanowire arrays facilitate gene delivery. Small 15(47):1904819. https://doi.org/10.1002/ smll.201904819

150. Elnathan R, Delalat B, Brodoceanu D, Alhmoud H, Harding FJ, Buehler K, Nelson A, Isa L, Kraus T, Voelcker NH (2015) Maximizing transfection efficiency of vertically aligned silicon nanowire arrays. Adv Funct Mater 25(46):7215-7225. https://doi.org/10.1002/adfm.201503465

151. Kim W, Ng JK, Kunitake ME, Conklin BR, Yang P (2007) Interfacing silicon nanowires with mammalian cells. J Am Chem Soc 129(23):7228-7229. https://doi.org/10.1021/ja071456k

152. Huang X, Li Z, Wu J, Hang Y, Wang H, Yuan L, Chen H (2019) Small addition of $\mathrm{Zn}(2+)$ in $\mathrm{Ca}(2+) @ \mathrm{DNA}$ results in elevated gene transfection by aminated PGMA-modified silicon nanowire arrays. J Mater Chem B 7(4):566-575. https://doi.org/10.1039/C8TB03045F

153. Chang R, Yan Q, Kingshott P, Tsai W-B, Wang P-Y (2020) Harnessing the perinuclear actin cap ( $\mathrm{nnAC}$ ) to influence nanocarrier trafficking and gene transfection efficiency in skeletal myoblasts using nanopillars. Acta Biomater 111:221-231. https://doi.org/10.1016/j.actbio.2020.05.015
154. Yang Y, Kulangara K, Sia J, Wang L, Leong KW (2011) Engineering of a microfluidic cell culture platform embedded with nanoscale features. Lab Chip 11(9):1638-1646. https://doi.org/10.1039/c0lc00736f

155. McKee CT, Raghunathan VK, Nealey PF, Russell P, Murphy CJ (2011) Topographic modulation of the orientation and shape of cell nuclei and their influence on the measured elastic modulus of epithelial cells. Biophys J 101(9):2139-2146. https://doi.org/10.1016/j.bpj.2011.09.042

156. Jean RP, Gray DS, Spector AA, Chen CS (2004) Characterization of the nuclear deformation caused by changes in endothelial cell shape. J Biomech Eng 126(5):552-558. https://doi.org/10.1115/1.1800559

157. Shalek AK, Robinson JT, Karp ES, Lee JS, Ahn D-R, Yoon M-H, Sutton A, Jorgolli M, Gertner RS, Gujral TS, MacBeath G, Yang EG, Park H (2010) Vertical silicon nanowires as a universal platform for delivering biomolecules into living cells. Proc Natl Acad Sci 107:1870 LP-1871875

158. Wang H, Pan J, Chen H, Yuan L (2016) Application of polyethyleniminegrafted silicon nanowire arrays for gene transfection. Methods Mol Biol 1445:279-287. https://doi.org/10.1007/978-1-4939-3718-9_18

159. Kunath K, Merdan T, Hegener O, Häberlein H, Kissel T (2003) Integrin targeting using RGD-PEl conjugates for in vitro gene transfer. J Gene Med 5(7):588-599. https://doi.org/10.1002/jgm.382

160. Dhaliwal A, Lam J, Maldonado M, Lin C, Segura T (2012) Extracellular matrix modulates non-viral gene transfer to mouse mesenchymal stem cells. Soft Matter 8(5):1451-1459. https://doi.org/10.1039/C1SM06591B

161. Gojgini S, Tokatlian T, Segura T (2011) Utilizing cell-matrix interactions to modulate gene transfer to stem cells inside hyaluronic acid hydrogels. Mol Pharm 8(5):1582-1591. https://doi.org/10.1021/mp200171d

162. Shepard JA, Huang A, Shikanov A, Shea LD (2010) Balancing cell migration with matrix degradation enhances gene delivery to cells cultured threedimensionally within hydrogels. J Control Release 146(1):128-135. https:// doi.org/10.1016/j.jconrel.2010.04.032

163. Mantz A, Rosenthal A, Farris E, Kozisek T, Bittrich E, Nazari S, Schubert E, Schubert M, Stamm M, Uhlmann P, Pannier AK (2019) Free polyethylenimine enhances substrate-mediated gene delivery on titanium substrates modified with RGD-functionalized poly(acrylic acid) brushes. Front Chem 7:51. https://doi.org/10.3389/fchem.2019.00051

164. Tavano L, Muzzalupo R, Mauro L, Pellegrino M, Andò S, Picci N (2013) Transferrin-conjugated pluronic niosomes as a new drug delivery system for anticancer therapy. Langmuir 29(41):12638-12646. https://doi.org/10.1021/ la4021383

165. Jiang H, Wang S, Zhou X, Wang L, Ye L, Zhou Z, Tang J, Liu X, Teng L, Shen $Y(2018)$ New path to treating pancreatic cancer: TRAll gene delivery targeting the fibroblast-enriched tumor microenvironment. J Control Release 286:254-263. https://doi.org/10.1016/j.jconrel.2018.07.047

166. Xu Z, Shen G, Xia X, Zhao X, Zhang P, Wu H, Guo Q, Qian Z, Wei Y, Liang S (2011) Comparisons of three polyethyleneimine-derived nanoparticles as a gene therapy delivery system for renal cell carcinoma. J Transl Med 9(1):46. https://doi.org/10.1186/1479-5876-9-46

167. Jones SK, Lizzio V, Merkel OM (2016) Folate receptor targeted delivery of siRNA and paclitaxel to ovarian cancer cells via folate conjugated triblock copolymer to overcome TLR4 driven chemotherapy resistance. Biomacromolecules 17(1):76-87. https://doi.org/10.1021/acs.biomac.5b01189

168. Singh B, Maharjan S, Kim Y-K, Jiang T, Islam MA, Kang S-K, Cho M-H, Choi YJ, Cho C-S (2014) Targeted gene delivery via N-acetylglucosamine receptor mediated endocytosis. J Nanosci Nanotechnol 14(11):8356-8364. https://doi. org/10.1166/jnn.2014.9919

169. Martino MM, Mochizuki M, Rothenfluh DA, Rempel SA, Hubbell JA, Barker TH (2009) Controlling integrin specificity and stem cell differentiation in 2D and $3 \mathrm{D}$ environments through regulation of fibronectin domain stability. Biomaterials 30(6):1089-1097. https://doi.org/10.1016/j.biomaterials.2008.10.047

170. Garrigues HJ, Rubinchikova YE, DiPersio CM, Rose TM (2008) Integrin aVB3 binds to the RGD motif of glycoprotein B of Kaposi's Sarcoma-associated herpesvirus and functions as an RGD-dependent entry receptor. J Virol 82: 1570 LP-1571580

171. Mould AP, Komoriya A, Yamada KM, Humphries MJ (1991) The CS5 peptide is a second site in the IIICS region of fibronectin recognized by the integrin alpha 4 beta 1. Inhibition of alpha 4 beta 1 function by RGD peptide homologues. J Biol Chem 266(6):3579-3585. https://doi.org/10.1016/500219258(19)67834-8

172. Makarem R, Humphries MJ (1991) LDV: a novel cell adhesion motif recognized by the integrin alpha 4 beta 1. Biochem Soc Trans 19(4):380S. https://doi.org/10.1042/bst019380s 
173. Hu J, Zhu M, Liu K, Fan H, Zhao W, Mao Y, Zhang Y (2016) A biodegradable polyethylenimine-based vector modified by trifunctional peptide R18 for enhancing gene transfection efficiency in vivo. Plos One 11(12):e0166673. https://doi.org/10.1371/journal.pone.0166673

174. Wojtowicz AM, Shekaran A, Oest ME, Dupont KM, Templeman KL, Hutmacher DW, Guldberg RE, García AJ (2010) Coating of biomaterial scaffolds with the collagen-mimetic peptide GFOGER for bone defect repair. Biomaterials 31(9): 2574-2582. https://doi.org/10.1016/j.biomaterials.2009.12.008

175. Khew ST, Zhu XH, Tong YW (2007) An integrin-specific collagenmimetic peptide approach for optimizing Hep3B liver cell adhesion, proliferation, and cellular functions. Tissue Eng 13(10):2451-2463. https://doi.org/10.1089/ten.2007.0063

176. Zeltz C, Orgel J, Gullberg D (2014) Molecular composition and function of integrin-based collagen glues-Introducing COLINBRIs. Biochim Biophys Acta - Gen Subj 1840(8):2533-2548. https://doi.org/10.1016/j.bbagen.2 013.12 .022

177. Shekaran A, García JR, Clark AY, Kavanaugh TE, Lin AS, Guldberg RE, García AJ (2014) Bone regeneration using an alpha 2 beta 1 integrin-specific hydrogel as a BMP-2 delivery vehicle. Biomaterials 35(21):5453-5461. https:// doi.org/10.1016/j.biomaterials.2014.03.055

178. Gilbert M, Giachelli CM, Stayton PS (2003) Biomimetic peptides that engage specific integrin-dependent signaling pathways and bind to calcium phosphate surfaces. J Biomed Mater Res A 67(1):69-77. https://doi.org/10.1 002/jbm.a.10053

179. Hamano N, Negishi Y, Fujisawa A, Manandhar M, Sato H, Katagiri F, Nomizu M, Aramaki Y (2012) Modification of the C16Y peptide on nanoparticles is an effective approach to target endothelial and cancer cells via the integrin receptor. Int J Pharm 428(1-2):114-117. https://doi.org/10.1016/j.jpharm.2012.02.006

180. Patel R, Santhosh M, Dash J, Karpoormath R, Jha A, Kwak J, Patel M, Kim J (2018) lle-Lys-Val-ala-Val (IKVAV) peptide for neuronal tissue engineering. Polym Adv Technol 30:4-12. https://doi.org/10.1002/pat.4442

181. Frith JE, Mills RJ, Hudson JE, Cooper-White JJ (2012) Tailored integrinextracellular matrix interactions to direct human mesenchymal stem cell differentiation. Stem Cells Dev 21(13):2442-2456. https://doi.org/10.1089/ scd.2011.0615

182. Puchalapalli M, Mu L, Edwards C, Kaplan-Singer B, Eni P, Belani K, Finkelstein D, Patel A, Sayyad M, Koblinski JE (2019) The Laminin-a1 chain-derived peptide, AG73, binds to syndecans on MDA-231 breast cancer cells and alters filopodium formation. Anal Cell Pathol (Amst) 2019:9192516

183. Gobin AS, West JL (2003) Val-ala-pro-gly, an elastin-derived non-integrin ligand: smooth muscle cell adhesion and specificity. J Biomed Mater Res A 67(1):255-259. https://doi.org/10.1002/jbm.a.10110

184. Ruoslahti $E$ (1996) RGD and other recognition sequences for integrins. Annu Rev Cell Dev Biol 12(1):697-715. https://doi.org/10.1146/annurev.cellbio.12.1.697

185. Truong NF, Kurt E, Tahmizyan N, Lesher-Pérez SC, Chen M, Darling NJ, Xi W, Segura T (2019) Microporous annealed particle hydrogel stiffness, void space size, and adhesion properties impact cell proliferation, cell spreading, and gene transfer. Acta Biomater 94:160-172. https://doi.org/10.1016/j.a ctbio.2019.02.054

186. Perlstein I, Connolly JM, Cui X, Song C, Li Q, Jones PL, Lu Z, DeFelice S, Klugherz B, Wilensky R, Levy RJ (2003) DNA delivery from an intravascular stent with a denatured collagen-polylactic-polyglycolic acid-controlled release coating: mechanisms of enhanced transfection. Gene Ther 10(17): 1420-1428. https://doi.org/10.1038/sj.gt.3302043

187. Dhaliwal A, Maldonado M, Lin C, Segura T (2012) Cellular cytoskeleton dynamics modulates non-viral gene delivery through RhoGTPases. Plos One 7(4):e35046. https://doi.org/10.1371/journal.pone.0035046

188. Zhang K, Fang H, Qin Y, Zhang L, Yin J (2018) Functionalized scaffold for in situ efficient gene transfection of mesenchymal stem cells spheroids toward chondrogenesis. ACS Appl Mater Interfaces 10(40):33993-34004. https://doi. org/10.1021/acsami.8b12268

189. Kong HJ, Liu J, Riddle K, Matsumoto T, Leach K, Mooney DJ (2005) Non-viral gene delivery regulated by stiffness of cell adhesion substrates. Nat Mater 4(6):460-464. https://doi.org/10.1038/nmat1392

190. Modaresi S, Pacelli S, Whitlow J, Paul A (2018) Deciphering the role of substrate stiffness in enhancing the internalization efficiency of plasmid DNA in stem cells using lipid-based nanocarriers. Nanoscale 10(19):89478952. https://doi.org/10.1039/C8NR01516C

191. Chu C, Kong H (2012) Interplay of cell adhesion matrix stiffness and cell type for non-viral gene delivery. Acta Biomater 8(7):2612-2619. https://doi. org/10.1016/j.actbio.2012.04.014
192. Gupta M, Doss BL, Kocgozlu L, Pan M, Mège R-M, Callan-Jones A, Voituriez R, Ladoux B (2019) Cell shape and substrate stiffness drive actin-based cell polarity. Phys Rev E 99(1):12412. https://doi.org/10.1103/ PhysRevE.99.012412

193. Gupta M, Sarangi BR, Deschamps J, Nematbakhsh Y, Callan-Jones A, Margadant F, Mège R-M, Lim CT, Voituriez R, Ladoux B (2015) Adaptive rheology and ordering of cell cytoskeleton govern matrix rigidity sensing. Nat Commun 6(1):7525. https://doi.org/10.1038/ncomms8525

194. Sun M, Chi G, Xu JJ, Tan Y, Xu JJ, Lv S, Xu Z, Xia Y, Li L, Li Y (2018) Extracellular matrix stiffness controls osteogenic differentiation of mesenchymal stem cells mediated by integrin a5. Stem Cell Res Ther 9(1): 52. https://doi.org/10.1186/s13287-018-0798-0

195. Du J, Zu Y, Li J, Du S, Xu Y, Zhang L, Jiang L, Wang Z, Chien S, Yang C (2016) Extracellular matrix stiffness dictates Wnt expression through integrin pathway. Sci Rep 6(1):20395. https://doi.org/10.1038/srep20395

196. Prager-Khoutorsky M, Lichtenstein A, Krishnan R, Rajendran K, Mayo A, Kam Z, Geiger B, Bershadsky AD (2011) Fibroblast polarization is a matrix-rigiditydependent process controlled by focal adhesion mechanosensing. Nat Cell Biol 13(12):1457-1465. https://doi.org/10.1038/ncb2370

197. Zhang T, Gong T, Xie J, Lin S, Liu Y, Zhou T, Lin Y (2016) Softening substrates promote chondrocytes phenotype via RhoA/ROCK pathway. ACS Appl Mater Interfaces 8(35):22884-22891. https://doi.org/10.1021/acsami. 6 b07097

198. Cai L, Liu W, Cui Y, Liu Y, Du W, Zheng L, Pi C, Zhang D, Xie J, Zhou X (2020) Biomaterial stiffness guides cross-talk between chondrocytes: Implications for a novel cellular response in cartilage tissue engineering. ACS Biomater Sci Eng 6(8):4476-4489. https://doi.org/10.1021/acsbiomateria Is.0c00367

199. Grover CN, Gwynne JH, Pugh N, Hamaia S, Farndale RW, Best SM, Cameron RE (2012) Crosslinking and composition influence the surface properties, mechanical stiffness and cell reactivity of collagen-based films. Acta Biomater 8(8):3080-3090. https://doi.org/10.1016/j.actbio.2012.05.006

200. Davidenko N, Bax DV, Schuster CF, Farndale RW, Hamaia SW, Best SM, Cameron RE (2015) Optimisation of UV irradiation as a binding site conserving method for crosslinking collagen-based scaffolds. J Mater Sci Mater Med 27:14

201. Rioja A, Muniz-Maisonet M, Koob T, Gallant N (2017) Effect of nordihydroguaiaretic acid cross-linking on fibrillar collagen: in vitro evaluation of fibroblast adhesion strength and migration. AIMS Bioeng 4(2): 300-317. https://doi.org/10.3934/bioeng.2017.2.300

202. Hogrebe NJ, Gooch KJ (2016) Direct influence of culture dimensionality on human mesenchymal stem cell differentiation at various matrix stiffnesses using a fibrous self-assembling peptide hydrogel. J Biomed Mater Res A 104(9):2356-2368. https://doi.org/10.1002/jbm.a.35755

203. Krüger-Genge A, Hauser S, Neffe AT, Liu Y, Lendlein A, Pietzsch J, Jung F (2021) Response of endothelial cells to gelatin-based hydrogels. ACS Biomater Sci Eng 7(2):527-540. https://doi.org/10.1021/acsbiomaterials. 0c01432

204. Ludtke JJ, Sebestyén MG, Wolff JA (2002) The effect of cell division on the cellular dynamics of microinjected DNA and dextran. Mol Ther 5(5):579-588. https://doi.org/10.1006/mthe.2002.0581

205. Rappoport JZ, Simon SM (2003) Real-time analysis of clathrin-mediated endocytosis during cell migration. J Cell Sci 116:847 LP-847855

206. Liu X, Yang H, Liu Y, Gong X, Huang H (2019) Numerical study of clathrinmediated endocytosis of nanoparticles by cells under tension. Acta Mech Sin 35(3):691-701. https://doi.org/10.1007/s10409-019-00839-0

207. Ferguson JP, Huber SD, Willy NM, Aygün E, Goker S, Atabey T, Kural C (2017) Mechanoregulation of clathrin-mediated endocytosis. J Cell Sci 130:3631 LP-3633636

208. Baschieri F, Dayot S, Elkhatib N, Ly N, Capmany A, Schauer K, Betz T, Vignjevic DM, Poincloux R, Montagnac G (2018) Frustrated endocytosis controls contractility-independent mechanotransduction at clathrincoated structures. Nat Commun 9(1):3825. https://doi.org/10.1038/s414 67-018-06367-y

209. Han S, Pang M-F, Nelson CM (2018) Substratum stiffness tunes proliferation downstream of Wnt3a in part by regulating integrin-linked kinase and frizzled-1. J Cell Sci 131:jes210476

210. Park JS, Chu JS, Tsou AD, Diop R, Tang Z, Wang A, Li S (2011) The effect of matrix stiffness on the differentiation of mesenchymal stem cells in response to TGF-B. Biomaterials 32(16):3921-3930. https://doi.org/10.1016/j. biomaterials.2011.02.019 
211. Tian B, Ding X, Song Y, Chen W, Liang J, Yang L, Fan Y, Li S, Zhou Y (2019) Matrix stiffness regulates SMC functions via TGF- $\beta$ signaling pathway. Biomaterials 221:119407. https://doi.org/10.1016/j.biomaterials.2019.119407

212. Pang M, Teng Y, Huang J, Yuan Y, Lin F, Xiong C (2017) Substrate stiffness promotes latent TGF-beta1 activation in hepatocellular carcinoma. Biochem Biophys Res Commun 483(1):553-558. https://doi.org/10.1016/j.bbrc.201 6.12.107

213. Ruppender NS, Merkel AR, Martin TJ, Mundy GR, Sterling JA, Guelcher SA (2010) Matrix rigidity induces osteolytic gene expression of metastatic breast cancer cells. Plos One 5(11):e15451. https://doi.org/10.1371/journal. pone.0015451

214. Page JM, Merkel AR, Ruppender NS, Guo R, Dadwal UC, Cannonier S, Basu S, Guelcher SA, Sterling JA (2015) Matrix rigidity regulates the transition of tumor cells to a bone-destructive phenotype through integrin $\beta 3$ and TGF$\beta$ receptor type II. Biomaterials 64:33-44. https://doi.org/10.1016/j.biomateria |s.2015.06.026

215. Smith LR, Cho S, Discher DE (2018) Stem cell differentiation is regulated by extracellular matrix mechanics. Physiol (Bethesda) 33(1):16-25. https://doi. org/10.1152/physiol.00026.2017

216. Sun M, Chi G, Li P, Lv S, Xu J, Xu Z, Xia Y, Tan Y, Xu J, Li L, Li Y (2018) Effects of matrix stiffness on the morphology, adhesion, proliferation and osteogenic differentiation of mesenchymal stem cells. Int J Med Sci 15(3): 257-268. https://doi.org/10.7150/ijms.21620

217. Hadi A, Rastgoo A, Haghighipour N, Bolhassani A, Asgari F, Soleymani S (2018) Enhanced gene delivery in tumor cells using chemical carriers and mechanical loadings. Plos One 13(12):e0209199. https://doi.org/10.1371/ journal.pone.0209199

218. Zhou ZL, Sun XX, Ma J, Man CH, Wong AST, Leung AY, Ngan AHW (2016) Mechanical oscillations enhance gene delivery into suspended cells. Sci Rep 6(1):22824. https://doi.org/10.1038/srep22824

219. Soleymani S, Hadi A, Asgari F, Bolhassani* NH and A (2019) Combination of mechanical and chemical methods improves gene delivery in cell-based HIV vaccines. Curr Drug Deliv. 16:818-828, 9, doi: https://doi.org/10.2174/1 567201816666190923152914

220. Hadi A, Rastgoo A, Bolhassani A, Haghighipour N (2019) Effects of stretching on molecular transfer from cell membrane by forming pores. Soft Mater 17(4):391-399. https://doi.org/10.1080/1539445X.2019.1610974

221. Chalberg TW, Vankov A, Molnar FE, Butterwick AF, Huie P, Calos MP, Palanker DV (2006) Gene transfer to rabbit retina with electron avalanche transfection. Invest Ophthalmol Vis Sci 47(9):4083-4090. https://doi.org/10.11 67/iovs.06-0092

222. Geiger RC, Taylor W, Glucksberg MR, Dean DA (2006) Cyclic stretch-induced reorganization of the cytoskeleton and its role in enhanced gene transfer. Gene Ther 13(8):725-731. https://doi.org/10.1038/sj.gt.3302693

223. Taylor W, Gokay KE, Capaccio C, Davis E, Glucksberg M, Dean DA (2003) The effects of cyclic stretch on gene transfer in alveolar epithelial cells. Mol Ther 7(4):542-549. https://doi.org/10.1016/S1525-0016(03)00041-8

224. Sinha B, Köster D, Ruez R, Gonnord P, Bastiani M, Abankwa D, Stan RV, Butler-Browne G, Vedie B, Johannes L, Morone N, Parton RG, Raposo G, Sens P, Lamaze C, Nassoy P (2011) Cells respond to mechanical stress by rapid disassembly of caveolae. Cell 144(3):402-413. https://doi.org/10.1016/j.cell.2 010.12 .031

225. Gervásio OL, Phillips WD, Cole L, Allen DG (2011) Caveolae respond to cell stretch and contribute to stretch-induced signaling. J Cell Sci 124:3581 LP3583590

226. Echarri A, Muriel O, Pavón DM, Azegrouz H, Escolar F, Terrón MC, SanchezCabo F, Martínez F, Montoya MC, Llorca O, Del Pozo MA (2012) Caveolar domain organization and trafficking is regulated by Abl kinases and mDia1. J Cell Sci 125:3097-3113

227. Tamura K, Mizutani T, Haga H, Kawabata K (2010) Nano-mechanical properties of living cells expressing constitutively active RhoA effectors. Biochem Biophys Res Commun 403(3-4):363-367. https://doi.org/10.1016/j. bbrc.2010.11.036

228. Baschieri F, Le Devedec D, Elkhatib N, Montagnac G (2019) Frustration of endocytosis potentiates compression-induced receptor signaling. 133(17): jcs239681. https://doi.org/10.1242/jcs.239681

229. Leontiadou H, Mark AE, Marrink SJ (2004) Molecular dynamics simulations of hydrophilic pores in lipid bilayers. Biophys J 86(4):2156-2164. https://doi. org/10.1016/S0006-3495(04)74275-7

230. Andree C, Voigt M, Wenger A, Erichsen T, Bittner K, Schaefer D, Walgenbach K-J, Borges J, Horch RE, Eriksson E, Stark GB (2001) Plasmid gene delivery to human keratinocytes through a fibrin-mediated transfection system. Tissue Eng 7(6):757-766. https://doi.org/10.1089/107632701753337708

231. Zhang Y, Zhang L, Li Y, Sun S, Tan H (2014) Different contributions of clathrin- and caveolae-mediated endocytosis of vascular endothelial cadherin to lipopolysaccharide-induced vascular hyperpermeability. Plos One 9(9):e106328. https://doi.org/10.1371/journal.pone.0106328

232. Stoeber M, Stoeck IK, Hänni C, Bleck CKE, Balistreri G, Helenius A (2012) Oligomers of the ATPase EHD2 confine caveolae to the plasma membrane through association with actin. EMBO J 31(10):2350-2364. https://doi.org/1 0.1038/emboj.2012.98

233. Walker M, Rizzuto P, Godin M, Pelling AE (2020) Structural and mechanical remodeling of the cytoskeleton maintains tensional homeostasis in $3 \mathrm{D}$ microtissues under acute dynamic stretch. Sci Rep 10(1):7696. https://doi. org/10.1038/s41598-020-64725-7

234. Lee H, Eskin SG, Ono S, Zhu C, McIntire LV (2019) Force-history dependence and cyclic mechanical reinforcement of actin filaments at the single molecular level. J Cell Sci 132:jcs216911

235. Fumoto S, Yamamoto T, Okami K, Maemura Y, Terada C, Yamayoshi A, Nishida K (2021) Understanding in vivo fate of nucleic acid and gene medicines for the rational design of drugs. Pharmaceutics 13(2). https://doi. org/10.3390/pharmaceutics13020159

236. Ishikawa H, Ma Z, Barber GN (2009) STING regulates intracellular DNAmediated, type I interferon-dependent innate immunity. Nature 461(7265): 788-792. https://doi.org/10.1038/nature08476

\section{Publisher's Note}

Springer Nature remains neutral with regard to jurisdictional claims in published maps and institutional affiliations.

\section{Submit your manuscript to a SpringerOpen ${ }^{\circ}$ journal and benefit from:}

- Convenient online submission

- Rigorous peer review

- Open access: articles freely available online

High visibility within the field

- Retaining the copyright to your article

Submit your next manuscript at $\boldsymbol{\nabla}$ springeropen.com 